\title{
Chimpanzés também amam: a linguagem das emoções na ordem dos primatas
}

\author{
E unice Ribeiro D urham \\ Professora aposentada do D epartamento de A ntropologia-U SP \\ Coordenadora do N U PE S-U SP
}

RESUMO : 0 objetivo deste artigo é o de chamar a atenção dos antropólogos para novos desenvolvimentos das ciências biológicas como os da Neurobiologia, da Primatologia e da E tologia, assim como os estudos recentes referentes à evolução. 0 resultado destes trabalhos recentes devem promover uma revisão das pressuposições antropológicas presentes na clássica oposição entre natureza e cultura. Este problema geral é analisado através de uma comparação entre homens e chimpanzés, a qual focaliza os componentes emocionais de comportamento dessas espécies, mais especificamente ainda, 0 artigo privilegia a análise do comportamento "amoroso", incluindo 0 sexual, e aquele presente nas relações entre mães e filhos, irmãos e amigos. Além disto, o trabalho também analisa a importância dos componentes emocionais para a constituição e preservação dos grupos sociais. Uma breve menção é feita quanto a hierarquia, agressão e alianças políticas. A comparação efetuada levanta questões referentes o incesto, à homossexualidade e 0 casamento, envolvendo um diálogo com a Psicanálise.

PALAVRAS-CHAVE: chimpanzés; cultura humana e comportamento animal; homem e outros primatas.

\section{Introdução}

O objetivo do trabalho é o de chamar a atenção para uma questão que foi abandonada pela antropologia recente e raramente considerada pela 
psicanálise: 0 fato de que, apesar da óbvia singularidade do comportamento humano, envolto como está numa espessa nuvem de símbolos e valores dentro da qual se move a consciência, o homem ainda é um animal, produto da evolução biológica, e compartilha com as demais estruturas e processos básicos sobre os quais e com os quais a cultura é construída.

A comparação entre o homem e os outros animais, especialmente os que nos são evolutivamente mais próximos, é particularmente importante, a meu ver, para estabelecer o contexto no qual podemos colocar de modo mais adequado as especificidades do comportamento humano.

A questão da evolução do homem e dos fundamentos biológicos da cultura humana constituiu uma preocupação importante da antropologia desde seu nascimento até meados do século passado, embora a ausência de uma base sólida de conhecimentos genéticos tenha impedido um tratamento adequado do tema, especialmente no que diz respeito à relação entre raça, cultura e evolução. Apesar disso, a contribuição da antropologia do final desse período foi muito importante para o desmonte do darwinismo social e das explicações da diversidade cultural em termos raciais. ${ }^{1}$

No que tange a estruturas geneticamente herdadas, é verdade que, mais recentemente, Lévi-Strauss recorreu à hipótese de um inconsciente humano universal, geneticamente determinado, uma máquina estruturante responsável pela possibilidade do processo de construção de sistemas simbólicos, como mitos e estruturas de parentesco. Mas, nessa concepção, o inconsciente é vazio, constituído apenas de mecanismos que organizam os conteúdos os mais variáveis. É uma capacidade do cérebro humano, um processo mental que transforma eventos em símbolos organizados em sistemas - a análise decorrente dessa postura é necessariamente formal, estando mais interessada no desvendamento dos 
códigos que permitem a comunicação entre os homens do que no substrato emocional que permeia as ações humanas. Trata-se, na verdade, de uma antropologia muito especial, que tem sido caracterizada como excessivamente intelectualista. ${ }^{2}$

Tanto no estruturalismo lévi-straussiano, como fora dele, tem predominado, na teoria antropológica recente, a concepção de que o processo evolutivo humano esteve associado a um enfraquecimento ou flexibilização dos instintos, de tal monta que é perfeitamente possível e mesmo necessário eliminar quaisquer considerações sobre possíveis bases instintivas na explicação do comportamento cultural. As orientações teóricas predominantes têm trabalhado com a concepção básica da oposição entre natureza e cultura, na qual esta é praticamente reduzida à dimensão simbólica do comportamento social. Afirma-se, de fato, que, nos seres humanos, a evolução da cultura substitui a evolução biológica e a natureza humana aparece como praticamente liberta de condicionantes genéticos.

Entretanto, se podemos tentar separar os homens dos demais animais em função da consciência, do raciocínio, da linguagem e do instrumental simbólico culturalmente construído, as emoções constituem claramente algo que compartilhamos com eles. É difícil deixar de reconhecer que animais sentem raiva e medo, alegria ou satisfação, ciúmes e desapontamento, como nós, e desenvolvem relações afetivas com outros animais, inclusive com seres humanos. As semelhanças comportamentais não se reduzem à dimensão emotiva - mas esta é certamente aquela na qual elas podem ser observadas da forma mais imediata, inclusive porque surgem e podem ser comunicadas independentemente da razão e mesmo da consciência. Constituem, por isso mesmo, um canal privilegiado de comunicação entre nós e os demais animais, como pode ser atestado por qualquer pessoa que tenha cães ou gatos em casa. 
Além disso, como já havia afirmado D arwin (e depois foi repetido por Malinowski), as emoções constituem uma base inicial de compreensão entre portadores de culturas diversas.

Não podemos subestimar as emoções. 0 que seria a vida humana sem alegrias e tristezas, raiva, amor e ódio?

Na antropologia clássica, a questão da relação entre razão e emoção foi objeto quase exclusivo da atenção de Lévy-Bruhl, cuja obra, ao mesmo tempo extremamente original e intensamente criticada, foi recentemente resgatada no Brasil por Roberto Cardoso de Oliveira (1991).

D os clássicos pós-evolucionistas, apenas Malinowski dedicou-se a essa problemática. Entretanto, a fragilidade da construção teórica malinowskiana, voltada para a definição de necessidades básicas e derivadas (assim como o contexto evolucionista da obra de Lévy-Bruhl), desacreditou o conjunto de suas contribuições que incluíam também uma atenção particular dedicada aos aspectos emocionais da vida social. No caso de Malinovski, entretanto, esses aspectos, que ele definia como "a carne e o sangue" das culturas, em oposição a seu esqueleto estrutural, são os responsáveis por muito da riqueza da tradição etnográfica que ele iniciou (Malinowski, 1992). São exatamente esses componentes afetivos que me interessam neste trabalho.

D e fato, é muito difícil, senão impossível, entender plenamente, descrever competentemente e explicar convincentemente um mito, um ritual mágico-religioso, uma transação comercial ou uma briga de galos, sem a observação e a referência às atitudes emocionais subjacentes, implícitas ou explícitas. E, na vida social em geral, não se pode ignorar que interesses e conflitos amorosos assim como rivalidades parecem constituir preocupações centrais dos homens vivendo em sociedade. Não deixa de ser um tanto contraditório que as vivências emotivas continuem presentes na descrição etnográfica sem levantar nenhuma inquietação teórica relevante. 
Revista de Antropologia, São Paulo, USP, 2003, v. 46 № 1.

Talvez por isso mesmo, os antropólogos tenham demonstrado um interesse episódico mas recorrente pela psicanálise, disciplina esta voltada exatamente para as bases emocionais e instintivas do comportamento humano. Além disso, as normas culturais que organizam o comportamento humano raramente são produtos da consciência e raramente operam através dela. Assim, as emoções bem como a questão do inconsciente constituem limites da reflexão antropológica, os quais os antropólogos têm tentado transpor recorrendo à psicanálise. 0 próprio Lévi-Strauss não ficou imune a esse interesse (Lévi-Strauss, 1958). A aproximação maior e mais sistemática entre antropologia e psicanálise é, entretanto, mais antiga e ocorreu nos Estados Unidos, nas décadas de 1930 e 1940, com o tema da relação entre personalidade e cultura, o qual envolveu a estreita colaboração de antropólogos e psicanalistas e mesmo algumas conversões de um campo para outro. Mas, mesmo nesses estudos, o interesse dos antropólogos ainda estava centrado na flexibilidade do equipamento genético humano e a na capacidade da cultura de, por assim dizer, modelar personalidades diferentes nas diversas sociedades.

Por outro lado, mesmo na psicanálise a questão das emoções e dos instintos é colocada de forma um tanto paradoxal, pois se ela fundamenta o desenvolvimento psíquico humano sobre a base instintiva fornecida pela sexualidade e se as emoções constituem a matéria-prima do trabalho clínico, há de fato, na tradição propriamente freudiana, muito pouco de uma teoria das emoções, que são em grande parte explicadas como meras decorrências de repressões ou gratificações de pulsões sexuais. Por outro lado, especialmente no que diz respeito à vida instintiva, as indubitáveis semelhanças com outros animais raramente foram levadas em consideração, embora pudessem ajudar a esclarecer muitas questões teóricas relevantes.

Freud, certamente, tinha consciência da importância das biociências para a psicanálise. É difícil encontrar um outro autor que busque de 
forma tão compulsiva quanto Freud uma integração teórica e uma base científica para suas descobertas empíricas no trabalho clínico. Por isso mesmo, e dado o fato de que ele foi levado a considerar a sexualidade como uma espécie de força motriz básica da psique humana, não podia ignorar o problema da conceituação do comportamento instintivo. Ele aborda a questão no seu célebre artigo "O s instintos e suas vicissitudes" (cuja primeira versão data de 1915), no qual estabelece uma distinção fundamental entre os instintos sexuais e os do ego. Nesse artigo encontramos um excelente exemplo do rigor intelectual de Freud, quando reconhece que a ciência de sua época não oferece elementos suficientes para elucidar plenamente a questão.

Tenho as maiores dúvidas de que se possa chegar a indicadores decisivos para a diferenciação e classificação dos instintos a partir (apenas) da elaboração do material psicológico. Esta própria elaboração parece exigir, até certo ponto, a aplicação de suposições definidas concernentes à vida instintiva àquele material e seria desejável que estas suposições pudessem ser extraídas de algum outro ramo de conhecimento e levadas para a psicologia. (Freud, 1914, p. 130)

Tendo em vista essa posição de Freud, não deixa de ser estranho que os psicanalistas, tanto quanto os antropólogos, tenham se desinteressado de acompanhar a intensa produção científica sobre essa questão que marca o último meio século.

De fato, nesse período, houve um extraordinário desenvolvimento de outras áreas de conhecimento que são diretamente relevantes para a compreensão das bases biológicas do comportamento animal e humano. Refiro-me às pesquisas mais recentes da psicologia experimental e do desenvolvimento e, inclusive, da psicologia cognitiva; às descobertas decorrentes do estudo dos hormônios e de sua influência nos processos 
orgânicos e psíquicos; ao desenvolvimento da neurobiologia e especialmente dos estudos do cérebro; aos espantosos progressos na área da genética molecular e sua influência na renovação da teoria da evolução; à primatologia e, especialmente, às pesquisas de etologia, particularmente no que diz respeito aos primatas. Parece-me que as demais disciplinas voltadas para o estudo do comportamento humano e, dentre estas, particularmente a psicanálise e a antropologia, não podem continuar confinadas dentro de seus estreitos limites disciplinares, mas precisam incorporar o resultado desse recente progresso científico como parte do contexto mais amplo no qual ocorrem os fenômenos que estudam.

Não se trata, obviamente, de defender um novo determinismo biológico. Reconhecer semelhanças não implica ignorar diferenças. Mas, como seres humanos, não nos movemos exclusivamente no universo rarefeito da razão e dos sistemas simbólicos. Ao contrário, o comportamento humano brota de um espesso caldo emocional que permeia sua vida social e que, poderíamos argumentar, é responsável tanto pelas atitudes mais nobres como pelos problemas mais dolorosos enfrentados cotidianamente nas sociedades humanas.

É por essa razão que, neste artigo, focalizei a questão geral dos laços genéticos e das semelhanças comportamentais que nos unem às demais espécies no problema das emoções. Restringi ainda mais a abordagem, centrando a reflexão nos sentimentos amorosos. Finalmente limitei a comparação e a reflexão sobre as semelhanças e diferenças tomando como base os chimpanzés.

A escolha dos chimpanzés não é aleatória, pois são, genética e evolutivamente, nossos parentes mais próximos. Além disso, qualquer um que tenha assistido a documentários sobre esses animais, ou os tenha observado em jardins zoológicos, não pode ter deixado de ficar perturbado por sua semelhança conosco. ${ }^{3}$ Eles são, em si mesmos, uma provocação constante à hubris humana que nos leva a desconsiderar nosso lado animal. 
Por outro lado, foi estratégica a escolha dos sentimentos amorosos como foco de comparação, não só por se tratar daquele campo no qual as emoções são particularmente importantes para a vida social, mas também porque é aquele no qual, com a ausência de uma reflexão antropológica, podemos nos socorrer da psicanálise, para a qual esta questão é central.

\section{As emoções}

Abordar a questão das semelhanças e diferenças entre nós e os chimpanzés da perspectiva do comportamento emocional esbarra na dificuldade de encontrar uma definição científica adequada das emoções e uma classificação consensual.

É verdade que há alguns aspectos próprios do comportamento emotivo que têm sido apontados desde uma época bastante longínqua. Uma característica fundamental das emoções, reconhecida desde Aristóteles, é o fato de elas não emergirem da consciência, de serem dificilmente controladas por ela e de influírem sobre ela. Esse fato nos remete a padrões geneticamente transmitidos e ao inconsciente.

O utra característica importante, associada a esta primeira, é sua expressão corporal automática e involuntária, o que torna difícil ocultálas e disfarçá-las. D e fato,

São os aspectos compulsivos das emoções - a absorção total [single mindedness] do estar apaixonado, a amargura inevitável do sentir-se rejeitado, a busca consumidora da vingança - que originam na sociedade ocidental tanto nossas atitudes positivas quanto negativas em relação às emoções. A partir do final do século XIX, pesquisadores começaram a se interessar pelos aspectos físico-corporais das emoções, que prometiam au- 
Revista de Antropologia, São Paulo, USP, 2003, v. 46 № 1.

xiliar uma maior compreensão sobre o modo pelo qual as emoções nos afetam involuntariamente. (Jenkins et al., 1998, p. 7)

Esses trabalhos constituíram, na verdade, uma peça importante na inclusão da espécie humana no processo evolutivo, tanto do ponto de vista físico como psíquico, como fica claro no trabalho de $\mathrm{D}$ arwin, publicado em 1890, intitulado A expressão das emog̣oes no homem e nos animais. ${ }^{4}$ D o mesmo ano, data outro livro fundamental sobre as emoções humanas, o de William James, The Principles of Psychology, no qual 0 caráter compulsivo das emoções, sua relação com os instintos e sua expressão corporal involuntária são extensamente analisados.

D e fato, a psicologia experimental acumulou, desde então, um extenso conhecimento relativo a condicionantes internos e externos que organizam o comportamento animal. Entretanto, a predominância do behaviorismo, com sua negativa em analisar aspectos subjetivos da conduta em nome de um cientificismo racionalista, promoveu um afastamento das preocupações com as emoções. Apenas mais recentemente essa posição tem se alterado. Por outro lado, a concentração do trabalho experimental sobre espécies não humanas, associada muitas vezes a generalizações um tanto apressadas sobre a significação dos resultados para a compreensão do comportamento do homem, tem obscurecido, para os cientistas sociais, a relevância desses estudos. Mesmo as investigações específicas sobre seres humanos, talvez por serem excessivamente focalizadas em aspectos muito determinados da conduta, têm sido em grande parte ignoradas pelas demais disciplinas que têm o homem como objeto de estudo.

D o lado oposto, o desenvolvimento de um tipo particular de evolucionismo, o da sociobiologia, centrado no gene, que se tornou popular a partir do livro de Dawkins, The selfish gene (1976), tem sido freqüentemente compreendido de forma mecanicista, reduzindo a complexa 
organização do comportamento animal a uma mera competição entre genes. Nessa visão, que ignora a complexidade e a riqueza das concepções de D awkins, o organismo, o grupo e a espécie se dissolveram e os genes, de fato, passaram a se assemelhar a indivíduos em competição constante. $O$ correm inclusive deslizes de linguagem através dos quais os genes parecem ser dotados de interesses e intenções. Essa concepção é de tal forma limitada e reducionista, especialmente quando aplicada ao homem que, compreensivelmente, contribuiu para justificar a suspeita generalizada das ciências humanas relativamente ao reconhecimento da importância do equipamento genético na modelagem do comportamento humano. Mas o evolucionismo contemporâneo não pode ser reduzido a essa generalização apressada e indevida.

Se a tradição da psicologia e do evolucionismo biológico não foi suficientemente utilizada pelas ciências humanas, 0 impacto recente da neurobiologia e da abordagem sobre as emoções, que ela introduziu, começa a produzir uma nova inquietação. Prova disso é o grande sucesso da publicação do belo trabalho de divulgação científica de Daniel Goleman, Inteligência emocional. Igualmente significativa é a publicação em português de dois livros recentes do neurobiólogo António D amásio: 0 erro de D escartes: emoção, razão e 0 cérebro humano e 0 mistério da consciência. D o corpo e das emoções ao reconhecimento de si. A contribuição central de Damásio consiste em demonstrar a estreita interdependência entre razão e emoção. Ao mesmo tempo em que valoriza uma abordagem evolutiva e, portanto, a importância das semelhanças entre o homem e os demais animais, reconhece que há muito de especificamente humano em nossa experiência das emoções: é o modo como se vinculam a idéias, valores, princípios e juízos complexos, isto é, sua manifestação como sentimentos e sua vinculação à consciência. Também reconhece que 0 aprendizado e a cultura interferem na expressão das emoções, reprimem algumas e estimulam outras e lhes conferem 
Revista de Antropologia, São Paulo, USP, 2003, v. 46 № 1.

novos significados. Por isso mesmo, sua obra parece-me particularmente relevante para psicanalistas e antropólogos.

As emoções "são processos determinados biologicamente e dependem de mecanismos estabelecidos de modo inato, assentados em uma longa história evolutiva (...) são parte de um conjunto de estruturas que regulam e representam estados corporais", acionados automaticamente sem uma reflexão consciente, a qual, quando ocorre, é posterior.

As emoções afetam o modo de operação de circuitos cerebrais e são responsáveis por mudanças profundas no corpo e no cérebro. As emoções se situam, evolutivamente, numa posição intermediária entre os mecanismos básicos de sobrevivência (regulação do metabolismo, reflexos simples, biologia da dor e do prazer) e a emergência dos mecanismos responsáveis pelo raciocínio. Estão associadas aos primeiros na medida em que fazem parte do instrumental de regulação da vida e desempenham um papel importantíssimo na relação dos organismos com o mundo externo; e ao segundo, na medida em que constituem a base dos sentimentos elaborados pela consciência. (Damásio, 2000, p. 75-76)

E moções podem ser provocadas por estímulos internos ou externos. Especialmente no caso de mecanismos externos é preciso reconhecer, mesmo para os animais, sobretudo no caso dos mamíferos superiores, a existência de uma variação considerável nos tipos de estímulos que podem induzir uma emoção e a forma da ação que eles desencadeiam, a qual é selecionada em função da experiência individual ou social e, portanto, depende não apenas de condicionantes genéticos, mas também do aprendizado. A experiência influi nos mecanismos biologicamente pré-ajustados, tanto modelando o que constitui um indutor para determinadas emoções, como influindo na sua expressão. No caso dos seres humanos, a variação é muito maior porque a cultura modela tanto 0 
comportamento decorrente da emoção como o seu conhecimento-reconhecimento. Estamos longe, portanto, de um novo determinismo genético. Mas a base inconsciente e geneticamente transmitida dos sentimentos não pode ser eliminada; sentimentos e mesmo a consciência dependem do substrato emocional.

A posição básica de $D$ amásio que nos interessa particularmente aqui é a de que a

(...) razão não pode ser tão pura como a maioria de nós pensa que é ou gostaria que fosse, e que emoções e sentimentos podem não ser de todo uns intrusos no bastião da razão, podendo encontrar-se, pelo contrário, enredados em suas teias, para o melhor e para o pior. É provável que as estratégias da razão humana não se tenham desenvolvido, quer em termos evolutivos, quer em termos de cada indivíduo em particular, sem a força orientadora dos mecanismos dos quais emoções e sentimentos são expressões notáveis. Além disso, mesmo depois de as estratégias de raciocínio se estabelecerem durante os anos de maturação, a atualização efetiva de suas potencialidades depende provavelmente, em larga medida, de um exercício continuado da capacidade de sentir emoções. (D amásio, 1984)

As observações acima, referentes às relações entre emoção e razão, certamente se aplicam com igual ou maior pertinência às dimensões simbólicas do comportamento.

Mais importante ainda do que a neurobiologia, para uma reaproximação da antropologia (e talvez da psicanálise) com as ciências biológicas, é o desenvolvimento da etologia, especialmente no que concerne às pesquisas baseadas na observação do comportamento dos primatas em seu ambiente natural. Esses estudos, aliás, são recentes. Embora a psicologia experimental com primatas em geral e chimpanzés em particular tenha uma história bem mais longa (o trabalho pioneiro de Köhler foi 
feito na década de 1920 assim como o de Yerkes), ${ }_{1}^{5}$ as observações de campo sistemáticas e prolongadas com chimpanzés vivendo em estado natural praticamente só tiveram início no final da década de 1950. Seus resultados começaram a se tornar conhecidos uma década depois. ${ }^{6}$ A documentação em vídeo que tem sido divulgada recentemente pela televisão nos programas sobre vida animal tornou os chimpanzés amplamente conhecidos do público em geral, mas as pesquisas não promoveram ainda um trabalho comparativo interdisciplinar sistemático com as ciências do homem.

No que diz respeito ao comportamento, especialmente ao emocional, a observação dos animais na natureza por períodos prolongados, que acompanham a sucessão de gerações, é essencial. A pesquisa em laboratório fragmenta o comportamento em função do set experimental. Além disso, trabalha com animais que vivem em cativeiro, situação que deforma enormemente sua vida psíquica. Essa deformação é particularmente séria no caso de animais sociais como os chimpanzés, praticamente eliminando, como ocorre com freqüência, a vida grupal na qual o comportamento normalmente se desenvolve. Animais sociais artificialmente confinados apresentam freqüentemente, quando comparados aos exemplares vivendo em seu ambiente natural, comportamentos patológicos no que diz respeito a seu desenvolvimento emocional, incluindo impotência, angústia, depressão, passividade e alheamento. Tem havido, é verdade, um esforço para tornar a situação de cativeiro mais semelhante à vida natural. A limitação diminui, mas não desaparece. Entretanto, exatamente, porque permite observações controladas, a contribuição dos estudos realizados em laboratório não pode ser desprezada, especialmente quando associada às observações feitas com animais selvagens.

Por outro lado, a psicologia experimental com primatas e particularmente com chimpanzés esteve voltada basicamente para estudos refe- 
rentes à cognição, ao raciocínio e à linguagem. É esta a área na qual se desenvolveram procedimentos e testes extremamente sofisticados, como as tentativas de ensinar chimpanzés a falar e a contar. ${ }^{7}$ Parece que, de modo geral, os pesquisadores estão basicamente interessados em investigar quão semelhantes aos homens os chimpanzés podem se tornar. 0 que me interessa, entretanto, neste trabalho, é a questão inversa: quão semelhantes aos chimpanzés nós somos, especialmente da perspectiva emocional, o que só pode ser investigado quando se analisam os chimpanzés em seus relacionamentos naturais com 0 ambiente e uns com os outros. Deixarei de lado, por isso, outras questões relevantes como a comunicação em geral, a cooperação grupal e a fabricação de instrumentos, as análises sobre inteligência, que não podem ser todas abordadas nos limites de um artigo.

\section{0 amor}

Ante a inexistência de um conceito propriamente antropológico relativo às emoções amorosas, tomei como referência a palavra amor, em lugar de algum dos inúmeros conceitos através dos quais filósofos, psicanalistas e psicólogos tentaram precisar e restringir os contornos pouco definidos do uso comum da palavra: eros, libido, afeto etc. Pareceu-me que, se vamos falar de emoções, o melhor seria empregar o termo mais emotivamente carregado. De fato, 0 amor, em suas diferentes acepções e traduções culturais, constitui uma preocupação básica e um problema permanente para homens e mulheres, adultos e crianças de todas as sociedades humanas (os psicanalistas que o digam), incluindo a mim e a todos os leitores deste artigo, o que pode provocar uma sensibilidade maior do leitor na análise do comportamento dos chimpanzés. 
Como palavra da linguagem comum o termo é, por isso mesmo, bastante impreciso, sendo utilizado em diferentes contextos, com significações variáveis. Mas a escolha do termo usado na nossa linguagem comum e favorecido na literatura tem a vantagem, para o antropólogo, de captar a amplitude de um amplo campo semântico que cobre uma grande variedade de relações emocionais positivamente carregadas que permeiam a vida social nas culturas ocidentais, campo este a partir do qual se elaboraram os conceitos científicos ou filosóficos. E, se é verdade que, como todo antropólogo sabe, a palavra não é encontrada em todas as línguas e o campo semântico varia de uma cultura para outra, 0 termo amor é suficientemente amplo para dar conta da maioria das manifestações de laços afetivos reconhecidas em outras culturas.

Um campo semântico implica a existência de um centro de significação que se espraia de modo variado por terrenos mais ou menos amplos que variam não só conforme a língua, mas, dentro de um mesmo idioma, conforme 0 contexto.

Tentemos procurar um núcleo de significação na tradição ocidental, de origem judaico-cristã, no qual se constituiu o nosso conceito de amor, para tentar verificar a possibilidade de que ele seja utilizado para compreender a vida emocional do chimpanzé.

É importante lembrar que, na herança mais próxima da tradição propriamente judaica, tal como se expressa na tradução dos Dez Mandamentos para as línguas ocidentais, esse núcleo de significação aparece como injunção ou obrigação. A palavra amor, entretanto, é utilizada apenas em relação a D eus e aparece logo no primeiro mandamento: "amar a D eus sobre todas as coisas". Relações entre pai e filho aparecem no terceiro mandamento, mas aqui não se diz que se deve amar pai e mãe, mas honrá-los. 0 amor sexual, por outro lado, aparece apenas numa proibição: "não cobiçar a mulher do próximo". E aquilo que po- 
deríamos chamar de amor fraterno ampliado surge como injunção de perdoar as ofensas. ${ }^{8}$

A tradição propriamente cristã ampliou e valorizou o amor: assim, não só devemos amar a D eus, mas se insiste que D eus nos ama (embora não houvesse, da parte dele, esta obrigação); esposos também devem se amar; além disso, devemos amar ao próximo como a nós mesmos; 0 amor dos filhos para com os pais e mães também constitui uma obrigação, embora o amor materno e paterno apareça como algo tão espontâneo ou natural que não parece haver a necessidade de um mandamento explícito.

Na medida em que essa tradição religiosa permeou as representações coletivas da cultura ocidental dominante até o século XIX, estabeleceuse uma divisão muito nítida entre diferentes tipos de amor. D e um lado, o amor exclusivamente espiritual, voltado para D eus, próprio e exclusivo dos seres humanos. No pólo oposto, 0 amor associado à atração sexual, designado como amor carnal, manifestação por excelência de animalidade, permeado por isso mesmo pelo pecado e apenas aceito na medida em que o desejo sexual é redimido pela necessidade da procriação ou por sua associação ao amor espiritual que lhe é conferida pelo sacramento do matrimônio. No meio, localiza-se 0 amor entre pais e filhos e especialmente entre mãe e filho, com maior componente espiritual, pois não é concebido estando contaminado pela sexualidade, embora decorra dela. Finalmente, há campo um tanto mais indefinido, que tem como paradigma 0 amor fraterno e que inclui desde relações interindividuais de amizade até 0 amor inteiramente espiritual que deve abranger "o próximo" ou a humanidade de forma geral. Reconhece-se a existência do desejo sexual sem amor, que é por excelência a manifestação da carne que deve ser combatida. As formas particularmente pecaminosas de amor são aquelas que confundem categorias que deveriam se manter separadas, contaminando-as com a sexualidade - 0 incesto, 
a homossexualidade, 0 adultério e a bestialidade - isto é, a sexualidade fora do casamento, impossível de ser sacramentada por ele e autônoma em relação à procriação.

D e fato, a oposição carne-espírito organizou a teologia do amor e, mesmo que seu rigor dogmático estivesse muito longe da prática cotidiana e do senso comum, ela certamente influenciou as representações coletivas como uma teoria do amor, valorizando seu componente espiritual.

Examinando essa tradição, podemos dizer que, na civilização ocidental, os principais núcleos de significados da palavra amor correspondem a um amor "espiritual", que constitui claramente uma elaboração psicocultural dependente da construção simbólica; ao amor relacionado ao sexo; ao amor entre mães, pais e filhos; e, finalmente, aquele associado à sociabilidade, que é própria dos animais sociais e que tem como paradigma a fraternidade.

Não é preciso dizer que Freud praticamente destruiu essa teoria milenar. Em primeiro lugar, eliminou D eus; em seguida, praticamente subsumiu todas as demais consagradas manifestações do amor sob o domínio da sexualidade. Pior ainda, transformou o desejo do incesto, de uma anomalia quase impensável, na pedra fundamental da organização psíquica. Jung foi mais moderado: restabeleceu D eus, embora sob a forma de "idéia de D eus", mantendo-0, entretanto, num domínio próprio, diferente do de Eros. Além disso, preservou-se, no núcleo do conceito de Eros, seu componente sexual, reconheceu esporadicamente um outro tipo de amor que denominou Libido de Parentesco. Finalmente, o componente sexual das relações pais-filhos, especialmente mãe-filho, não assumiu em Jung a dominância que Freud lhe atribuíra.

Entretanto, apesar da grande influência da psicanálise e da contribuição junguiana, as teorias tradicionais, incorporadas no senso comum, persistem ainda e podem nos orientar na análise do amor entre os chimpanzés. ${ }^{9}$ 
D os componentes que distinguimos como centrais no significado do amor humano, um pelo menos está ausente entre os chimpanzés: 0 amor a D eus, ao que tudo indica, como já afirmavam os teólogos, só existe para os seres humanos - chimpanzés, como todas as demais espécies, não têm nenhum conhecimento dele; ignoram, portanto, o chamado amor espiritual, o qual certamente emerge das elaborações simbólicas que nos distinguem dos demais animais. Os três restantes, entretanto - 0 amor associado à sexualidade; 0 amor entre pais, mães e filhos; e o amor ao próximo, ou sociabilidade - , encontram paralelos na sociedade chimpanzé embora as diferenças sejam tão importantes quanto as semelhanças.

Para falar de chimpanzés, entretanto, precisamos fazer uma breve referência aos primatas conhecidos como antropóides.

\section{Antropóides e chimpanzés}

Da perspectiva evolutiva fazemos parte dos primatas chamados antropóides os quais, além de nós, incluem (em ordem de maior proximidade genética e evolutiva) os chimpanzés, gorilas, orangotangos e gibões.

O s chimpanzés, especialmente, são extremamente próximos de nós, pois partilhamos com eles mais de $95 \%$ do nosso equipamento genético. De fato, geneticamente, a diferença entre os chimpanzés e nós é menor do que a existente entre eles e os gorilas.

A literatura recente tem separado, como espécie diversa, os chimpanzés conhecidos como bonobos nos quais, além de diferenças estatísticas na proporção dos membros inferiores e superiores e menor dimorfismo sexual, podem ser detectadas diferenças comportamentais significativas; as quais incluem atividade sexual mais intensa, menor agressividade, dominância menos marcada por parte dos machos e grupos maiores. Utili- 
zaremos neste trabalho, como referência básica, os chimpanzés "tradicionais", isto é, Pan troglodytes, sobre os quais a bibliografia é muito maior e nos referiremos aos bonobos, Pan panisaus, de modo secundário. ${ }^{10}$

Chimpanzés são, como nós, animais sociais e vivem em grupos relativamente estáveis de 30 indivíduos em média, que podem variar de 10 até mais de 100, e incluem crianças, jovens e adultos de ambos os sexos. As relações entre membros de um mesmo grupo são bastante intensas e, diríamos mesmo, altamente emocionais. Os chimpanzés estão constantemente se comunicando uns com os outros, através de vocalizações, posturas corporais, expressões faciais e contato físico como agressões e carícias. D os antropóides são certamente os mais barulhentos e os mais expressivos. Além disso, são tomados freqüentemente por explosões emocionais, e isso em qualquer idade e sexo, o que os faz parecerem crianças mal-educadas.

O s grupos não são amorfos. ${ }^{11}$ Há uma clara estrutura de dominação dos machos sobre as fêmeas e os machos imaturos são dominados pelos adultos de ambos os sexos. Entre os machos adultos um, denominado na literatura macho alfa, lidera o grupo. A hierarquia entre os machos não é nem permanente nem pacífica - boa parte da vida social consiste em reafirmar ou contestar posições de dominação, através de demonstrações de agressividade e submissão. Há também uma hierarquia entre as fêmeas, mas menos clara e menos competitiva.

Além disso, a organização dos grupos inclui um complexo processo de fusão-fissão, isto é, de subdivisão e reunião associadas à procura de alimentos, no qual preferências afetivas e relações de parentesco interferem de modo pronunciado. Além do mais, a própria competição por posições na hierarquia envolve aliança e coalizões igualmente marcadas por relações interpessoais preferenciais. ${ }^{12}$

A vida em grupos desse tipo, que incluem diferentes machos adultos, é encontrada entre outras espécies de primatas, mas não nos demais 
antropóides não humanos. Gibões, por exemplo, vivem em pequenos grupos formados por um casal e seus filhos imaturos. O rangotangos são animais solitários, que se aproximam apenas durante 0 cio, para uma breve convivência; os pequenos grupos existentes consistem em uma fêmea com suas crias imaturas, raramente, aliás, mais de uma. Gorilas, por outro lado, apresentam variações na composição dos grupos: a maior parte deles inclui apenas um macho adulto com diversas fêmeas e os filhos imaturos, mas há também bandos que incluem até quatro machos adultos. ${ }^{13}$

D entro desse quadro geral podemos começar a analisar semelhanças e diferenças entre nós e os chimpanzés no que diz respeito ao comportamento amoroso, começando pela sexualidade a qual claramente possui bases instintivas e envolve alta carga emocional.

\section{Sexualidade e promiscuidade}

Chimpanzés, especialmente os bonobos, são animais que demonstram tanto um enorme interesse pelo sexo como um grande espectro de atividades eróticas, que incluem diferentes posições corporais na cópula, masturbação e carícias hetero e homoeróticas. Além disso, a freqüência de contatos sexuais é muito elevada.

D uas características fundamentais organizam a sexualidade entre os chimpanzés e ambas diferem dos padrões humanos - são, por isso mesmo, muito interessantes do ponto de vista comparativo.

Em primeiro lugar, como em praticamente todos os animais sexuados, com exceção do homem, o acasalamento é controlado por ciclos periódicos de fertilidade e infertilidade das fêmeas, isto é, por períodos de cio de duração limitada. É basicamente durante esses períodos que as fêmeas são, simultaneamente, atraentes para os machos e recepti- 
Revista de Antropologia, São Paulo, USP, 2003, v. 46 № 1.

vas às relações sexuais. Fora desses períodos, as relações entre machos e fêmeas são, em grande parte, assexuadas, embora as diferenças de gênero permaneçam.

Em muitas espécies animais, esses ciclos costumam ser anuais e regulados pelos períodos de maior abundância de alimentos. Quando isso ocorre, todas as fêmeas entram no cio mais ou menos ao mesmo tempo e a atividade sexual de machos e fêmeas fica restrita a um período muito breve do ano. Não é isso que ocorre com os chimpanzés e com diversos outros primatas. Não existe uma sazonalidade coletiva nos períodos de cio das fêmeas, que apresentam ciclos individuais de fertilidade, interrompidos pela gravidez e amamentação. Isso significa que, embora as fêmeas individualmente estejam freqüentemente indisponíveis para relações sexuais, a existência de múltiplas fêmeas num mesmo bando garante que haja, com freqüência, alguma no cio, o que oferece, para os machos, múltiplas oportunidades de relacionamento sexual durante todo 0 ano. 0 cio das fêmeas é marcado por um inchaço muito visível da parte externa dos órgãos sexuais, que adquirem um colorido rosa intenso. Quanto maior o inchaço, que é mais pronunciado nas fêmeas plenamente adultas e férteis, maior a desejabilidade das fêmeas e maior 0 interesse dos machos por elas.

O tipo de periodização do cio das fêmeas e os padrões de acesso dos machos às fêmeas no cio constituem, para os animais sociais, um elemento fundamental de organização dos grupos. Uma forte tendência ao monopólio de fêmeas por parte de um macho dominante impede a existência de grupos sociais amplos. Utilizando de forma metafórica conceitos que se aplicam mais propriamente a seres humanos, diríamos que esse monopólio impede a existência de "sociedades" e restringe o grupo a "famílias". No caso dos gibões, por exemplo, entre os quais os grupos abrangem apenas um par adulto e sua prole imatura, a estrutura é semelhante a uma "família monogâmica". Nesse tipo de organização, a 
oportunidade de atividade sexual é muito restrita, tanto para machos como para fêmeas, pois é interrompida pelos longos períodos de gravidez e amamentação. Em muitas espécies de mamíferos, encontramos um outro tipo de organização que é freqüente também entre os gorilas: a formada por um único macho adulto dominante e diversas fêmeas, com as crias subadultas. ${ }^{14}$ Nesse caso, temos grupos maiores, semelhantes a uma única "família poligínica", ocorrendo então oportunidades mais freqüentes de relações sexuais para os machos. A constituição de grupos grandes ou "sociedades" propriamente, com a coexistência de machos e fêmeas adultos de uma forma relativamente permanente, depende da quebra do monopólio de acesso sexual às fêmeas por um único macho dominante.

A "solução", no caso da sociedade chimpanzé (como em algumas outras espécies de primatas sociais), fundamenta-se na promiscuidade, que oferece a todos os machos do grupo oportunidades freqüentes de exercício da sexualidade, uma vez que, em grupos grandes, é comum que pelo menos uma fêmea esteja no cio e disposta a copular com diferentes machos.

A promiscuidade é certamente uma característica extremamente interessante da vida social dos chimpanzés e responsável pelo fato de que a sexualidade permeie de forma muito intensa toda a vida social. A promiscuidade, aliás, parece ser uma possibilidade sempre presente entre os antropóides; mesmo entre gibões e gorilas, em havendo oportunidade, fêmeas e machos podem eventualmente copular com adultos de outros grupos. E bandos de gorilas podem incluir mais de um macho, caso em que a promiscuidade se estabelece.

Convém lembrar, entretanto, que a promiscuidade não é nem irrestrita nem igualitária. Em primeiro lugar, é em grande parte limitada aos membros do grupo. Relações sexuais fora do grupo, embora ocorram, são objetos de repressão, freqüentemente agressiva por parte dos mem- 
bros do bando. Por outro lado, as relações entre grupos, que são freqüentemente hostis e violentas, estão associadas às tentativas de preservar ou aumentar o número de fêmeas do bando. De fato, a sexualidade parece constituir um dos elementos fundamentais para a constituição e manutenção de grupos estáveis.

Em segundo, dentro do grupo, os machos dominantes asseguram um acesso privilegiado às fêmeas, especialmente as mais desejáveis, isto é, nas quais o volume e a cor do inchaço genital são mais pronunciados. Mas mesmo machos dominantes particularmente ciumentos dificilmente conseguem monopolizar uma ou mais fêmeas as quais, dada a presença de diferentes machos, o padrão de dispersão do grupo na procura de alimentos e a proteção da folhagem, parecem encontrar com razoável facilidade oportunidades de encontros amorosos diversificados, inclusive com machos de outros grupos.

D urante o período do cio as fêmeas copulam diversas vezes por dia. A freqüência da cópula é difícil de ser estabelecida nas pesquisas de campo porque os animais ficam freqüentemente ocultos pela vegetação. Nesse ponto, estudos feitos com animais em cativeiro, que podem ser observados todo o tempo, oferecem informações importantes, mesmo quando se considera que, nessa situação, estando os animais liberados das tarefas de procurar alimento e de se defender de predadores, a sexualidade provavelmente é intensificada.

As tabelas apresentadas por Waal, decorrentes de 15 anos de observações sistemáticas e controladas na colônia do zoológico de Arnhem (na qual se procurou uma aproximação das condições da vida selvagem), indicam que durante 0 período do cio as fêmeas copulam uma média de seis vezes por dia. As fêmeas adolescentes, mesmo que ainda não férteis, demonstram um entusiasmo copulativo muito maior: uma média de dez vezes por dia, o que está associado ao fato de elas freqüentemente tomarem a iniciativa e se oferecerem aos machos. As fêmeas adultas, ao 
contrário, raramente tomam a iniciativa que, nestes casos, é predominantemente masculina (Waal, 1989, p. 146).

A cópula, propriamente, é muito breve e dura geralmente 15 segundos, estendendo-se, quando muito, a um minuto. Pode, entretanto, ser repetida uma ou duas vezes após breves intervalos. As fêmeas, especialmente as jovens, às vezes gritam no momento em que, aparentemente, atingem o orgasmo. Os machos se limitam a emitir grunhidos rítmicos. Após a cópula, os parceiros se separam sem maiores cerimônias (idem).

Não há, entretanto, como duvidar do grande interesse que os chimpanzés manifestam pelo sexo e de sua importância para a dinâmica da constituição dos grupos.

Uma observação de Fossey sobre os gorilas se aplica integralmente aos chimpanzés:

(...) the presence of an estrus female, either an adolescent or a reproductively capable adult, prompts a great deal of vicarious sexual activity among other group members such as mounting between individuals of the same sex or between animals of different age group. Unisexual mounting occur twice as often between males as among females, while age discrepant mountings occur most often when adult males mount immature. (1983, p. 75)

Como há freqüentemente uma fêmea no cio e a presença dela provoca uma grande agitação no grupo, a sexualidade está muito presente na vida social de chimpanzés e gorilas tornando-a inclusive extremamente movimentada. $\mathrm{O}$ interesse pelo sexo, aliás, não se restringe aos adultos, mas se manifesta muito precocemente. A partir de dois anos, filhotes de ambos os sexos ficam extremamente excitados quando observam 0 ato sexual dos adultos e interferem ativa e barulhentamente, quer tentando impedi-lo quer, mais freqüentemente, tentando participar dele (Goodall, 1988). 
Revista de Antropologia, São Paulo, USP, 2003, v. 46 № 1.

Há também, entre os chimpanzés imaturos, contatos eróticos freqüentes durante as brincadeiras, do tipo que Freud caracteriza, para os seres humanos, como perverso polimorfo. Nessa fase, parece que as diferenças entre machos e fêmeas não estão ainda consolidadas no plano instintivo e breves manipulações genitais, assim como tentativas de montar o parceiro, ocorrem indiscriminadamente, independentemente de sexo.

Podemos certamente falar de um instinto sexual..$^{15}$ Melhor seria, entretanto usar a palavra pulsão, que deriva da tradução francesa do termo Trieb utilizado por Freud. ${ }^{16} \mathrm{~A}$ palavra pulsão é mais adequada do que instinto porque admite uma variabilidade na forma através da qual a necessidade de satisfação do impulso se realiza. De fato, chimpanzés, como seres humanos, apresentam comportamentos sexuais bastante flexíveis. É importante lembrar também que, para Freud, a pulsão se coloca entre o propriamente físico e o psíquico. Mesmo nesse sentido, creio que o conceito pode ser aplicado aos chimpanzés e primatas em geral.

Além dos aspectos já mencionados que demonstram a flexibilidade do comportamento sexual, é importante notar também que varia bastante 0 grau de entusiasmo por sexo, especialmente entre as fêmeas, e isto desde a adolescência. Enquanto algumas apresentam um comportamento que, na espécie humana, poderia ser caracterizado como ninfomaníaco, outras parecem recear os machos e cruzam com muito menos freqüência. Há também preferências sexuais que não impedem a promiscuidade, mas estabelecem relações mais próximas e mais duradouras entre um par específico. 0 capítulo 7 ("A vida sexual de Flo") do livro de Jane G oodall (1988) oferece uma descrição bastante vívida do comportamento sexual dos chimpanzés.

Como entre muitos outros primatas, a masturbação também ocorre e é um tipo de comportamento particularmente freqüente entre os bonobos de ambos os sexos, mas especialmente entre as fêmeas. Entre 
os bonobos, aliás, relações homossexuais entre fêmeas também são comuns: fêmeas no cio se abraçam e esfregam horizontalmente os genitais, parecendo obter grande satisfação com este ato. Também entre os bonobos, contatos genitais entre machos são freqüentes, como fricção mútua do pênis, mas parecem ser antes uma atividade de apaziguamento e solidariedade do que uma forma de obter satisfação sexual, porque são muito breves, não produzem ejaculação e ocorrem em situações de tensão grupal. Aliás, a forma mais comum de contato genital entre os machos consiste em esfregarem rapidamente os traseiros, sem contato entre os pênis (Waal, 1997).

D e um modo ou de outro, a observação do comportamento sexual dos chimpanzés parece não deixar dúvida de que, entre eles, o sexo é uma atividade altamente emocional, um interesse constante e desempenha uma importante função de relacionamento, tanto o promovendo como expressando outros tipos de relações afetivas. A apresentação do traseiro, por exemplo, que é característica das fêmeas no cio quando aceitam ou convidam um macho para a atividade sexual, é usada também por machos e fêmeas, indistintamente, para demonstrar submissão perante um macho dominante. Portanto, sexo ou, mais precisamente, contatos genitais não se restringem a uma atividade de procriação nem envolvem necessariamente a cópula (Hashimoto e Furuichi, 1994).

Um outro dado importante, sem dúvida nenhuma, é a deformação dos instintos sexuais que ocorre em cativeiro e, mais especialmente, em situações nas quais os animais são isolados e privados dos estímulos fornecidos pela vida grupal. Nessas circunstâncias, não só a masturbação se torna habitual e mesmo compulsiva, como se manifestam também outras anomalias como impotência, frigidez, estupro e infanticídio ou rejeição das crias pela mãe. Por isso mesmo, a reprodução em cativeiro é difícil e exige condições especiais de manejo ou interferência humana direta. Chimpanzés em cativeiro, como é o caso de muitos outros ani- 
mais, parecem, de fato, ter um comportamento sexual mais parecido com os dos seres humanos em termos de problemas sexuais e reprodutivos do que aquele que é característico dos animais selvagens, o que parece comprovar que somos animais autodomesticados. Aliás, Erich Fromm faz uma indicação interessante na mesma linha quando observa que as condições de vida do homem assemelham-se mais a de animais em jardim zoológico do que a de animais vivendo em seu ambiente natural (1975, p. 252). Isso comprova que o instinto sexual é flexível em termos de sua manifestação e depende da experiência social tanto entre chimpanzés como entre seres humanos. A diferença mais importante reside no fato de que chimpanzés, como os animais em geral, não elaboram julgamentos morais em relação à sexualidade.

Convém, entretanto, fazer algumas reflexões adicionais sobre a promiscuidade.

A promiscuidade está associada, como vimos, ao fato de que, entre os chimpanzés, relações sexuais não estabelecem parcerias permanentes, estáveis e muito menos exclusivas entre machos e fêmeas, apesar dos casos de preferências afetivas. Entre nós, ao contrário, o sexo e a reprodução são organizados, em todas as sociedades conhecidas, de forma a estabelecer parcerias pelo menos relativamente permanentes entre homens e mulheres, fortalecidas por uma divisão social do trabalho.

É interessante, de fato, especular sobre em que medida as parcerias sexuais humanas estabelecidas por diferentes formas de casamento constituem, com efeito, uma invenção cultural imposta sobre uma base instintiva promíscua. Isso explicaria o fato de 0 adultério, apesar de condenado em todas as culturas, parecer constituir uma espécie de tentação permanente e passatempo favorito para homens e mulheres no conjunto das sociedades humanas.

A pesar de não se poder extrapolar os padrões sexuais de uma espécie para outra, especialmente no caso de antropóides, há algumas indica- 
ções que tornam essa hipótese plausível. A principal delas é o fato da promiscuidade, tão clara entre os chimpanzés, permanecer, como vimos, como uma possibilidade sempre presente nos demais antropóides.

Se a hipótese é plausível, poderíamos realmente afirmar que o casamento, a parceria sexual estável tal como ocorre nas sociedades humanas, é um fenômeno propriamente cultural, sem fundamentação biológica (ao contrário do que acontece, por exemplo, entre os gibões). Somos então levados a indagar o que teria conduzido a humanidade a trilhar este caminho tão particular de investir no casamento e no estabelecimento de parcerias sexuais estáveis e as implicações deste caminho. Para isso, temos que voltar novamente ao estudo das diferenças.

A ausência do cio, isto é, a capacidade das fêmeas humanas de manterem relações sexuais independentemente do ciclo reprodutivo é uma delas. Nesse caso, parece ter ocorrido uma adaptação evolutiva no sentido de facilitar a formação de parcerias permanentes. 0 cio e a interrupção da sexualidade durante a gravidez e a amamentação, como ocorre entre os chimpanzés, tornam a fêmea indisponível para as relações sexuais durante um período muito prolongado, o que provavelmente criaria tensões dificilmente suportáveis para o parceiro masculino e para o grupo no caso de restrição da sexualidade a parceiros permanentes; quando outras fêmeas entrassem no cio a parceria estável dificilmente seria mantida a não ser com a poliginia (que cria outras tensões, excluindo inúmeros homens do acesso regular às fêmeas).

Por outro lado, o resultado dessa autonomia da sexualidade em relação aos ciclos reprodutivos é um espaçamento menor entre as gestações o que parece só ser possível sustentar dentro de grupos mais organizados, com formas mais complexas de cooperação econômica e social. Embora as mulheres sejam fisicamente capazes de ter um filho por ano, não poderiam arcar com a carga de cuidados envolvidos na maternidade se, como as mães chimpanzés, tivessem que prover sozinhas às suas 
próprias necessidades e às das crias. As sociedades humanas desenvolveram, é verdade, mecanismos culturais para aumentar o espaçamento das gestões, através de tabus e do infanticídio deliberado ou decorrente de abandono. ${ }^{17}$ Mas, mesmo assim, a taxa reprodutiva humana tende a ser superior a dos chimpanzés, o que deve estar relacionado à extraordinária expansão da nossa espécie pelo mundo todo, isto é, ao nosso sucesso evolutivo.

D eve-se ainda considerar que o casamento, entre os seres humanos, está inextricavelmente associado a dois outros fenômenos, também tipicamente humanos: a paternidade e o tabu do incesto, que convém estudar com maiores detalhes.

\section{Paternidade, maternidade e incesto}

Com a inexistência de pares estáveis, não há entre os chimpanzés nada correspondente a relações de paternidade (ou de avunculado) tão importantes entre nós, embora inúmeros estudos tenham apontado para 0 fato de que os machos tendem a ser extremamente tolerantes e protetores para com as crias das fêmeas do seu grupo (com as quais, aliás, em geral, tiveram relações sexuais). Machos são, de fato, tolerantes e mesmo carinhosos com os filhotes, que não lhes demonstram nenhum respeito: puxam-lhes os pêlos, sobem por suas costas e as usam como escorregador. Poderíamos mesmo imaginar algo semelhante a uma paternidade difusa. A disciplina da hierarquia começa a ser aplicada depois que os filhotes atingem 4 ou 5 anos, quando cessa a tolerância. Mas, nos casos de bebês pequenos que ficaram órfãos, há casos registrados nos quais machos lhes oferecem proteção especial e procuram mesmo atuar como mães substitutas (Mason, 1965, p. 527). ${ }^{18}$ 
Sobre este fenômeno que estou chamando de "paternidade difusa" convém citar um relato de Schaller, um dos primeiros pesquisadores a estudar sistematicamente os gorilas em seu ambiente natural. Embora o relato diga respeito aos gorilas e não aos chimpanzés, ilustra bastante bem o comportamento do macho dessas duas espécies de antropóides sociais em relação às crias das fêmeas de seu bando. Além disso, deixa transparecer a identificação emocional que o observador humano espontaneamente demonstra em relação aos animais. Seguindo o rastro de um bando de gorilas que haviam encontrado pouco antes, Schaller e seu companheiro D oc tomaram a crista de um vale e avistaram o bando na elevação do lado oposto; 0 macho, após gestos ameaçadores iniciais, acabou se tranqüilizando e sentando-se ao lado de uma fêmea com filhote, num montículo:

O macho, que devia pesar quase $200 \mathrm{Kg}$, permaneceu no montículo, contemplando montanhas e planícies, verdadeiro senhor de seus domínios. Uma outra fêmea, com um bebê suavemente estreitado contra o corpo, aproximou-se. "D eve ser um recém-nascido" - sussurrei para D oc. "Ainda está molhado" - ele concordou. A fêmea se apoiou pesadamente contra as costas do macho. Seu braço peludo quase ocultava completamente seu bebê, que parecia uma aranha e cujos finos braços e pernas se agitavam ao acaso. 0 macho se inclinou e, com a mão, acariciou o bebê. D urante duas horas, embevecidos, contemplamos aquela cena de família.

Schaller e seu companheiro tiveram finalmente que se afastar porque estava ficando tarde e tinham que retornar ao acampamento. Surpreso com o fato dos gorilas não terem se afastado como vinham fazendo então, Schaller especula: "Talvez não tivessem querido se afastar por causa do nascimento iminente ou recente do filhote" (1964, p. 50-51). ${ }^{19}$ 
A pesar do interesse e às vezes do carinho demonstrado pelos machos em relação aos recém-nascidos, não tendo pais, no sentido humano do termo, os chimpanzés estão certamente livres do complexo de Édipo e do tabu do incesto. Apesar disso, surpreendentemente, relações incestuosas são raras, especialmente porque (ao contrário de muitas outras espécies de primatas nas quais os adolescentes de sexo masculino tendem a se dispersar) entre os chimpanzés são as fêmeas adolescentes que tendem a espontaneamente buscar outros grupos logo após a menarca. Esse afastamento costuma se dar no período do cio, no qual elas se tornam atraentes para machos de outros grupos, os quais facilitam sua introdução no novo bando, protegendo-as da agressividade das outras fêmeas. Verifica-se, portanto, a existência de algo parecido com "uma troca de mulheres" espontânea (ou natural). Essa tendência natural torna raro tanto 0 incesto entre pai e filha quanto entre irmão e irmã. Há, entretanto, casos em que as fêmeas permanecem no grupo, especialmente quando são filhas de mães dominantes. As cuidadosas observações de Jane G oodall indicam, entretanto, que, mesmo nesses casos, as relações sexuais entre irmãos são raras. Parece que a convivência estreita entre irmãos, que analisaremos mais tarde, amortece a atração sexual. As observações relativas a incesto entre pai e filha são bem menos conclusivas, inclusive porque, na situação de promiscuidade e sem a introdução de testes genéticos sistemáticos para a população do grupo, nem os pesquisadores, nem os chimpanzés podem saber ao certo quem é o genitor. Podemos inferir que, nos casos relativamente raros nos quais a fêmea adolescente permanece no grupo, 0 incesto com o pai pode ocorrer, especialmente quando o genitor era e permanece sendo o macho dominante. Essa condição, entretanto, não deve ser muito freqüente, porque a posição de dominância raramente dura os sete ou oito anos necessários para uma fêmea iniciar o período reprodutivo. Além disso, fêmeas 
adolescentes raramente copulam com machos adultos - 0 acasalamento se dá preferencialmente com machos jovens.

Os dados mais surpreendentes, porém, dizem respeito ao incesto entre mães e filhos, os quais normalmente convivem no mesmo grupo. Em mais de trinta anos de observação consecutiva, Jane G oodall e sua equipe afirmam não terem conseguido registrar um único caso de incesto desse tipo. E, em observações prolongadas, ao contrário do que acontece com o genitor masculino, a filiação materna de adultos jovens é conhecida dos pesquisadores e, ao que parece, reconhecida pelos filhos. Também aqui o contato estreito e prolongado da cria com a mãe parece dificultar ou mesmo impedir a atração sexual. Nos demais estudos consultados, não encontrei informação específica sobre incesto, com exceção de uma breve referência de Dian Fossey sobre os gorilas: prosseguindo o relato que citamos anteriormente sobre a amplitude de atividades sexuais, afirma que as únicas parcerias que nunca foram observadas incluem machos imaturos montando machos adultos e machos montando suas mães (Fossey, 1983, p. 75).

Certamente esses dados não permitem concluir que o mesmo ocorra necessariamente entre os seres humanos e que as relações entre mãe e filho e entre irmãos inibam a atração sexual, mesmo porque o comportamento sexual, como já vimos, pode apresentar grandes variações de uma espécie para outra, mesmo em se tratando de espécies próximas. Entretanto, parece que os dados referentes aos chimpanzés devem, pelo menos, promover um reexame da questão do tabu do incesto e do complexo de É dipo tanto por parte dos antropólogos como dos psicanalistas, cujas concepções estão assentadas na certeza da existência de um forte desejo sexual entre mães e filhos e entre irmãos. No caso da antropologia, especificamente, podemos reanalisar a questão da troca de mulheres e do tabu do incesto que a estabelece e perguntar se, em lugar de uma ruptura radical entre natureza e cultura, não se trata antes de uma 
regulamentação cultural de um padrão natural preexistente. O bviamente o fato de pensarmos mais em termos de passagem ou transformação em lugar de ruptura não torna o fenômeno menos importante enquanto característica especificamente humana.

Para uma melhor compreensão dessa questão é necessário analisar detidamente as relações entre mães e filhos e entre filhos da mesma mãe.

\section{Mães e filhos}

Procuramos mostrar que a sexualidade permeia a vida social e constitui (junto com a dominação) um dos elementos fundamentais da sociabilidade chimpanzé, embora não crie parcerias, isto é, relações interindividuais permanentes. Esse tipo de relação é dado, entretanto, pela maternidade.

Entre os chimpanzés, como entre os seres humanos, os demais primatas e os mamíferos, em geral, as crias nascem muito imaturas e não sobrevivem sem cuidados maternos intensos e prolongados. Um dos aspectos cruciais desses cuidados é a amamentação a qual promove, necessariamente, uma relação estreita entre mãe e cria e faz com que 0 conjunto dos cuidados necessários a sobrevivência e desenvolvimento dos filhotes tenda a ser fornecido pela mãe. Na natureza, os filhotes de chimpanzés mamam com enorme freqüência, em intervalos que às vezes não ultrapassam 15 minutos, mas o ato de mamar é de curta duração, variando de poucos minutos e alguns segundos. D ormindo com as mães, provavelmente elas amamentam também durante à noite. Além do mais, entre os chimpanzés, o período de aleitamento é excepcionalmente longo, durando em geral de três a quatro anos, o que prolonga e provavelmente intensifica os laços que unem mães e crias. 
No caso dos primatas, a necessidade de cuidado materno permanente é ampliada pelo fato de que, em função da locomoção arborícola e ausência de pouso fixo, os filhotes precisam ser não somente alimentados, limpos e acariciados, mas inclusive permanentemente carregados. 0 contato físico é, portanto, constante. Primatas constroem apenas ninhos temporários para uma única noite e, ao contrário de cães, lobos, pássaros e tantos outros animais, não possuem ninhos ou tocas permanentes, nos quais as crias possam permanecer protegidas enquanto a mãe se afasta para prover sua própria alimentação (Mason, 1965).

Entre os chimpanzés, a dependência dos filhotes é não só intensificada pela necessidade de serem carregados, mas é ampliada pelo fato do seu desenvolvimento ser muito lento. Filhotes de chimpanzés adquirem alguma autonomia de movimentação apenas com um ano e, assim mesmo, só se locomovem sozinhos quando a mãe está perto e vigilante. $\mathrm{Na}$ permanente movimentação diária dos grupos em busca de alimento e, especialmente, numa reação de fuga ante uma ameaça externa, os filhotes continuam a ser carregados pelo menos até 4 anos e, excepcionalmente, até os 5. Como a amamentação também é prolongada, conforme vimos, as relações entre mães e filhos envolvem um grau de proximidade física mais intenso do que a observada no caso dos seres humanos.

A necessidade de se agarrar à mãe e de ser agarrado por ela, ou de estar sendo permanentemente segurado e apoiado, pode ser uma adaptação evolutiva da vida arbórea, na qual perder o apoio significa, freqüentemente, uma queda mortal. A reação de medo à sensação de queda, aliás, parece ser uma das reações mais primitivas do neonato humano.

Embora haja variações individuais, as mães chimpanzés demonstram, em relação às crias, comportamentos que são extremamente semelhantes ao que chamamos na nossa espécie de amor materno. A relação da mãe com as crias constitui, indubitavelmente, o laço mais forte existente na 
sociedade chimpanzé, e a este relacionamento caberia, a meu ver, a qualificação de amoroso e está amplamente documentado na bibliografia.

A adaptação evolutiva a esse grau de dependência é dupla. Em primeiro lugar, chimpanzés têm um filhote de cada vez. Encontrei um único caso documentado de nascimento de gêmeos entre chimpanzés selvagens, mas as crias não sobreviveram ao primeiro ano de vida. A segunda adaptação consiste no espaçamento entre as gestações. D ado o alto investimento físico das mães para assegurar a sobrevivência das crias, essas adaptações parecem de fato ser essenciais para assegurar o sucesso da procriação. Como vimos, fêmeas raramente retomam o cio antes de três anos após o parto (com exceção dos bonobos, entre os quais este período pode ser reduzido a um ano) e, mesmo entre os bonobos, raramente são férteis antes dos 3 ou 4 anos. Considerando-se uma gestação de 7,5 meses, o espaçamento médio entre as crias é em média de 4 a 6 anos. D urante esse tempo, a cria permanece em estreito contato físico com a mãe. Além disso, o nascimento de uma nova cria não interrompe o contato estreito com a cria anterior. É comum observar uma fêmea com uma cria no colo e outra maior, a seu lado. Em casos de perigo ou de uma travessia particularmente difícil, a mãe carrega também a cria mais velha montada em suas costas. Mesmo após a adolescência, chimpanzés continuam a manter contatos estreitos com as mães, defendendo-as ou sendo defendidos por elas em caso de perigo (Goodall, 1988).

Convém analisar melhor a questão do complexo comportamental associado ao contato físico tão estreito que decorre da amamentação e da locomoção. Em primeiro lugar, é importante considerar as observações experimentais sobre reflexos dos neonatos. Mason observa que os reflexos primários ou primitivos, que ocorrem nos recém-nascidos, obedecem a um padrão muito semelhante entre macacos, antropóides e seres humanos. Na revisão do material disponível na bibliografia sobre esses diferentes primatas Mason afirma: 
Entre os primeiros comportamentos coordenados a aparecer após o parto são aqueles que servem para manter contato corporal com a mãe e permitir a amamentação, a saber: movimentação da cabeça (que permite encontrar a teta), agarrar-se e mamar (incluindo sugar e engolir). Os três são encontrados entre seres humanos, inclusive o de agarrrar-se (grasp reflex ). ${ }^{20}$ (...) Embora estas respostas possam ser analisadas individualmente, elas estão funcionalmente inter-relacionadas não apenas nos neonatos, mas durante toda a infância. Assim a coordenação entre os reflexos de sugar e engolir durante a amamentação pode ser perturbada se os macaquinhos não estiverem firmemente agarrados. A ação de se agarrar é intensificada durante a amamentação, mesmo quando o infante está firmemente seguro. O bserva-se também que filhotes de macacos, chimpanzés e seres humanos abrem e fecham as mãos ou apresentam outras formas de movimentação dos dedos quando estão amamentando ou mesmo bebendo de uma xícara. (Mason, 1965, p. 517-19)

A liás, no que diz respeito à necessidade de contato corporal, Mason reproduz uma extensa observação de Alfred Russel Wallace sobre suas experiências relativas a um bebê orangotango capturado, que é interessante não apenas pela importância do observador como pela objetividade do relato e pela época em que foi escrito: 1869.

D urante os primeiros dias, ele se agarrava desesperadamente com as quatro mãos a qualquer coisa que conseguisse alcançar, e eu tinha que tomar cuidado para manter minha barba afastada, pois seus dedos se agarravam a superfícies peludas mais do que a qualquer outra coisa e era impossível eu me libertar sem ajuda. Q uando inquieto, ele movia os braços e as mãos no ar, tentando encontrar alguma coisa à qual pudesse se agarrar... Por falta de outra coisa, ele agarrava freqüentemente seus próprios pés e depois de 
Revista de Antropologia, São Paulo, USP, 2003, v. 46 № 1.

algum tempo, cruzava os braços e agarrava, com as mãos, os longos pêlos que cresciam no ombro oposto. (Wallace, apud Mason, 1965, p. 520)

Finalmente, Wallace providenciou um embrulho de pele de búfalo, que pareceu satisfazê-lo até descobrir que não havia tetas nele. As múltiplas observações desse tipo de comportamento entre os chimpanzés indicam que não estamos lidando com meros reflexos automáticos, mas com intensas manifestações emocionais.

D evemos enfatizar que a amamentação e as sensações corporais que derivam do contato com o corpo da mãe formam um complexo o qual inclui, além das sensações de maciez e dureza, também calor, cheiro, ritmo, gosto e ruídos (como os grunhidos carinhosos das mães chimpanzés ou mesmo as batidas do coração).

A importância do contato corporal contínuo com o corpo da mãe foi repetidamente comprovada em experiências de laboratório. Hinde demonstrou a existência de um padrão muito claro de reação de filhotes rhesus temporariamente separados de suas mães. Mesmo quando alimentados e deixados em seu ambiente habitual, podia-se comprovar uma seqüência constante de comportamentos que passavam de protesto e procura pela mãe para desespero e eram seguidos de apatia ou depressão profunda (Hinde, 1971). Estudos com bebês humanos internados em clínicas ou hospitais, separados das mães, revelaram o mesmo padrão. ${ }^{21}$

As observações de campo com chimpanzés comprovam essa seqüência. Bebês órfãos, mesmo quando podem se alimentar sozinhos e são objeto de cuidados especiais por parte de um irmão, irmã ou mesmo um macho adulto, raramente sobrevivem e parecem, literalmente, morrer de tristeza. Jane $\mathrm{G}$ oodall descreve cuidadosamente três casos desse tipo, em seu livro In the shadow of man. Diane Fossey faz observações equivalentes para órfãos de gorilas (1983). 
Tornaram-se também clássicas as experiências de Harlow e Zimmmerman, na década de 1960, nas quais filhotes de rhesus recém-nascidos eram colocados isolados em gaiolas com cilindros de arame, dos quais recebiam alimento, e cilindros recobertos de tecido felpudo, que não forneciam leite. Os macaquinhos se agarraram ao cilindro de arame apenas durante o tempo estritamente necessário para satisfazer a fome, correndo em seguida para as "mães" felpudas, às quais permaneciam agarrados o resto do tempo.

Resumindo e analisando o resultado desses trabalhos, a antropóloga e etóloga Sarah Hrdly afirma (talvez com certo exagero) que "dinging to a surrogate mother has everything to do with this notion of security and little to do with satisfying hunger" (2000, p. 399).

D e uma forma ou de outra, é certamente muito importante o fato de que o contato com a mãe pareça criar os primeiros laços afetivos e constituir a base sobre a qual se constroem os sentimentos de segurança física e emocional. Além disso, mães chimpanzés são uma fonte constante de proteção contra qualquer possível perigo externo e de estímulos sensoriais-motores. As mães estão sempre manipulando os filhotes limpando-os, catando-os, abraçando-os, acariaciando-os com os lábios - e brincando com eles: balançando-os no ar e fazendo-lhes cócegas. Em suma, parecem-se muito com mães humanas.

No desenvolvimento da psicanálise, a teoria sobre a natureza das experiências mais primitivas dos bebês humanos tomou inicialmente, com Freud, um rumo muito diferente, dificultando para os psicanalistas posteriores a incorporação destas observações relativas aos primatas em geral e chimpanzés em particular.

No ensaio sobre sexualidade infantil, que faz parte dos Três ensaios sobre a sex ualidade, Freud toma um caminho muito peculiar: ele considera 0 ato de sugar como manifestação mais primitiva da sexualidade, separando-o do "instinto" da alimentação, isto é, do ato de mamar. 0 
protótipo adotado é o ato de sugar o polegar. Crianças de fato sugam partes do seu próprio corpo além do seio materno, principalmente 0 polegar, mas é difícil separar esta atividade do complexo de respostas geneticamente estabelecidas que fazem parte do equipamento de sobrevivência das crianças, que inclui a amamentação. Filhotes de chimpanzés e outros primatas também desenvolvem o hábito de chupar o dedo, mas este comportamento, freqüente em situação de cativeiro e quando os filhotes não estão em contínua associação com as mães, é raro em animais vivendo em condições naturais a não ser durante o desmame, quando, além de seus próprios dedos e mãos, sugam também outras áreas do corpo materno, como as axilas.

Seria difícil, é verdade, mesmo para Freud, caracterizar a alimentação como uma manifestação da sexualidade. D e fato, Freud distinguiu inicialmente duas classes de instintos ou pulsões: erotismo e autopreservação (embora a esta última tenha dedicado pouca atenção). D ada essa classificação, a amamentação estaria necessariamente entre este último grupo. A autonomização do ato de sugar como fundamento do erotismo infantil teve um inconveniente fundamental que foi o de deixar de examinar o conjunto muito complexo e profundo de compulsões e sensações corporais que caracterizam a relação da mãe com o bebê.

É verdade que as posições de Freud não são monolíticas, e outras hipóteses relativas ao erotismo infantil são aventadas em outros artigos, sem que sejam integradas num todo coerente.

Michel Balint fez uma análise muito minuciosa e penetrante das diferentes posições assumidas por Freud e conclui: "É um fato curioso, porém de fácil verificação que durante muitos anos Freud tenha conservado três pontos de vista mutuamente exclusivos da relação mais primitiva do indivíduo e seu entorno" (1968, p. 31). A primeira é a do autoerotismo primário que está nos T rês ensaios, sobre o qual já nos referimos. 
A segunda, Balint encontra numa passagem de A interpretação dos sonhos, a qual cita:

Num momento em que as primeiras satisfações sexuais ainda estão ligadas à ingestão de alimentos, a pulsão sex ual tem um objeto sex ual fora do próprio crpo da criança, sob a forma do seio da mãe. Só mais tarde é que a pulsão perde este objeto, talvez exatamente no momento em que a criança se torna capaz de formar uma idéia total da pessoa a quem pertence o órgão que lhe está fornecendo satisfação. Como regra, então, a pulsão sexual se torna auto-erótica, e, somente após ter passado o período da latência, é restaurada a relação original. Estas são, pois, boas razões do mamar da criança no seio materno tornar-se o protótipo de toda relação de amor. (Freud apud Balint, 1968, p. 31)

A terceira hipótese diz respeito às reflexões sobre o narcisismo primário, nas quais afirma:

A forma mais primitiva de relação do indivíduo e seu entorno é 0 autoerotismo, seguido pelo estágio narcísico, a partir do qual então se desenvolvem as relações objetais. (Idem) $)^{22}$

D e qualquer forma, os inúmeros estudos posteriores sobre recémnascidos se orientam numa outra direção: contato corporal e alimentação parecem fazer parte de um complexo integrado que une mãe e filho de tal modo que os prazeres (eróticos ou não) dos bebês chimpanzés dificilmente se enquadrariam na concepção freudiana de auto-erotismo que perduraria até a fase edípica. 0 reexame da hipótese do auto-erotismo levaria a rever também a questão do narcisismo primário e o conceito de relações anaclíticas. 
Melanie Klein, a partir de algumas colocações do próprio Freud, deu um grande passo na análise das experiências e emoções infantis com a atenção que dedicou ao seio e à amamentação como base para o estabelecimento de relações primitivas com objetos externos.

Embora reconheça ocasionalmente outros aspectos da relação mãebebê, como o contato corporal, a teoria kleniana ficou de fato excessivamente centrada na amamentação. Ainda que posteriormente o conceito de "seio" tenha se ampliado, a própria preservação deste termo como conceito básico cria dificuldades semânticas para a compreensão mais ampla da relação mãe-bebê. A excessiva atenção à amamentação infantil e ao seio materno parece reduzir o psiquismo ou pelo menos o erotismo infantil à oralidade. ${ }^{23}$

Psicanalistas britânicos e húngaros, posteriormente, orientaram-se no sentido de ampliar a contribuição de Melanie Klein e rever de forma mais profunda o desenvolvimento infantil nas fases pré-genitais (oral e anal). A relação de objeto passa definitivamente a ter início nas fases pré-edípicas e envolve as múltiplas formas de contato com a mãe.

É muito significativa, nessa orientação, a formulação, por Winnicott, do conceito de holding (que pode significar abraço ou sustentação) 0 qual, como na linguagem comum, tem uma dupla referência, física e psicológica, e engloba a multiplicidade dos aspectos presentes na relação mãe-bebê (Winnicott, 1992, p. 263-71).

Essa distinção teórica, efetuada por Balint, encontra comprovação empírica nos trabalhos experimentais. Particularmente relevante, sobre esse aspecto, é a experiência efetuada pelo casal Kellog, que criou um filhote de chimpanzé com o próprio filho. A té os dois anos, o desenvolvimento mental e afetivo da criança e do chimpanzé demonstrou ser estritamente semelhante, com algumas vantagens para o chimpanzé quanto ao desenvolvimento motor. A partir, entretanto, do momento em que a criança começou a falar, o desenvolvimento deixou de ser comparável. ${ }^{24}$ 
A conclusão a que podemos chegar é a de que o processo de desenvolvimento dos seres humanos e dos chimpanzés segue praticamente 0 mesmo caminho até os 2 anos. Embora se diferencie posteriormente com a constituição da linguagem, estabelece estruturas psíquicas básicas que perduram durante a vida, testemunhando continuamente a proximidade do parentesco entre essas duas espécies.

D a perspectiva comparativa e evolutiva e na tradição psicanalítica, mais relevante ainda que a obra de Balint, é a de John Bowlby que alia a psiquiatria e a prática psiquiátrica à etologia evolucionista e à psicologia experimental.

Central na teoria de Bowlby é o conceito de attachment ou apego. A riqueza do conceito está em sua polissemia, incluindo aspectos físicos e psíquicos. A ttachment, em inglês, designa de um lado a ação física de unir, fixar ou juntar partes de um conjunto; corresponde, portanto, a conexão, ligação, fixação. De outro, attachment corresponde a atração, simpatia, afeto ou amor. D e fato, o conceito de Bowlby é explicitamente utilizado teoricamente para costurar essas duas dimensões. É semelhante ao conceito de holding, criado por Winnicott, e se aproxima do amor primário, proposto por Balint. ${ }^{25}$

D e fato, partindo da relação mãe-bebê, a elaboração do conceito de attachment efetuada por Bowlby praticamente cobre a área que estamos analisando com 0 termo amor e se encaminha na mesma direção. Entre as características do attachment, Bowlby inclui: a especificidade, isto é, o fato de o comportamento de ligação ser dirigido para indivíduos específicos; a duração, isto é, o fato de a ligação persistir, por grande parte do ciclo vital, embora possa ser atenuada e eventualmente substituída por outras. Para as finalidades deste trabalho, entretanto, a característica mais importante é o envolvimento emocional: 
Revista de Antropologia, São Paulo, USP, 2003, v. 46 № 1.

(...) muitas das emoções intensas durante a formação surgem da manutenção, rompimento e renovação de relações de ligação. A formação de um vínculo é descrita como "apaixonar-se", a manutenção de um vínculo como "amar alguém" e a perda de um parceiro como "sofrer por alguém". D o mesmo modo, a ameaça de perda gera ansiedade e a perda real produz tristeza; enquanto que cada uma dessas situações é capaz de suscitar raiva. A manutenção inalterada de um vínculo afetivo é sentida como uma fonte de júbilo. (Bowlby, 2001, p. 172)

E mbora, nesse trecho, a referência básica sejam os seres humanos, a conceituação tem um campo de aplicação muito maior e se aplica inteiramente aos chimpanzés. Aliás, o próprio autor, mais adiante, afirma que 0 attachment ocorre nos filhotes de quase todas as espécies de mamíferos, e em certas espécies (como chimpanzés) persiste durante toda a vida, e o desenvolvimento de sua teoria baseou-se em um amplo levantamento comparativo com especial atenção dedicada aos primatas.

$\mathrm{O}$ autor também afirma que, em sua teoria, "o comportamento de ligação é concebido como uma classe distinta do comportamento de alimentação e do comportamento sexual, tendo, pelo menos, um significado igual na vida humana" (idem, p. 174) e, podemos acrescentar, na vida dos chimpanzés. ${ }^{26}$

\section{"Instinto" materno}

A análise da relação entre mães e filhos levanta uma outra questão bem menos discutida na literatura - trata-se da existência de um "instinto" materno que parece ser a contrapartida necessária da dependência dos filhotes. Se as crias não sobrevivem sem mães, é necessário que estas estejam geneticamente programadas para suprir os cuidados dos quais os 
filhotes dependem. É impossível negar que essa programação esteja presente nos mamíferos de forma geral.

Entretanto, no caso dos seres humanos, se a palavra instinto é comumente e amplamente utilizada pelo senso comum no que se refere à sexualidade, ela tem sido muito mais contestada no caso da maternidade. 0 movimento feminista tem manifestado especial hostilidade ao conceito, que é interpretado como uma imposição masculina no sentido de naturalizar indevidamente a posição de subordinação das mulheres. ${ }^{27}$

Aliás, no que diz respeito aos antigos evolucionistas, a hostilidade é plenamente justificada, pois tendo definido a "natureza feminina" pela procriação, concluíram que, por esta razão, as mulheres não possuíam as faculdades mentais mais elevadas, as quais estariam restritas ao sexo masculino.

Mas combater os preconceitos machistas dos antropólogos evolucionistas não significa ignorar que a maternidade tem uma longa história evolutiva e assume, entre os mamíferos, particular relevância. Isso ocorre porque, na reprodução entre os mamíferos, como vimos, não só a cria nasce imatura e depende de cuidados constantes da parte de um adulto, mas porque estes cuidados envolvem 0 aleitamento e, portanto, implicam uma relação particularmente estreita com a mãe. A dedicação da mãe à prole, essencial à sobrevivência das crias, deve constituir uma característica genética complementar àquelas que marcam as necessidades e o comportamento dos bebês, envolvendo inclusive profundas modificações do equilíbrio hormonal que se desencadeiam durante a gestação e o parto e se fortalecem no próprio ato da amamentação. Essas transformações hormonais também estão presentes na espécie humana.

Não há nenhuma razão para supor que a evolução humana promovesse a diminuição desse instinto porque ele é tão essencial à sobrevivência da nossa espécie quanto no caso dos demais mamíferos. No que 
diz respeito à amamentação, convém lembrar que fórmulas seguras de aleitamento artificial datam de apenas um século (o que é menos que um segundo na história evolutiva) e, para a quase totalidade da humanidade, a privação do leite materno sempre significou altíssimos índices de mortalidade infantil. Nas sociedades humanas, a mãe pode ser substituída por uma ama de leite, prática relativamente restrita aos casos de morte da mãe, de insuficiência na produção de leite ou, após o início da civilização, como prática habitual nas classes dominantes. Esse procedimento, entretanto, até o século passado, tendeu a ser emergencial ou confinado às classes abastadas e nunca generalizado para a humanidade no seu conjunto. Mesmo hoje, na grande maioria da humanidade que habita os países subdesenvolvidos, o aleitamento materno continua a ser essencial para a sobrevivência dos filhos. Por outro lado, como já vimos, a relação de attachment da mãe para com a criança, em seus múltiplos aspectos, é essencial não só ao desenvolvimento físico mas também mental e emocional dos bebês.

Por isso mesmo, parece-me estranho que as disciplinas analíticas e a Antropologia tenham, na verdade, dedicado muito pouca atenção às implicações da possível existência de uma pulsão ou instinto materno. Não que a mãe tenha sido desconsiderada. A dependência, não só física, mas afetiva do bebê em relação à mãe, é plenamente reconhecida como fundante do desenvolvimento psíquico humano, conforme vimos anteriormente. Mas tanto na elaboração freudiana do complexo de Édipo, como nos conceitos junguianos de complexo e de arquétipo maternos, 0 fato psicológico fundamental é a experiência da criança. 0 que me parece negligenciado é a importância que a manifestação do instinto materno assume como elemento fundamental no desenvolvimento da psique feminina ou da feminilidade. $\mathrm{Na}$ abordagem junguiana, o conceito do arquétipo materno que, como todos os arquétipos, é pensado como estando baseado em estruturas psíquicas hereditárias, é difícil de 
ser compreendido se não estiver associado a pulsões maternas inatas. D essa perspectiva, o complexo ou arquétipo deveria ser pensado como resultante da confluência entre a necessidade infantil de cuidados maternos e a pulsão ou "instinto materno" que se concretiza na gestação e na relação com a prole.

N ovamente precisamos considerar a contribuição, na psicanálise, de Winnicott, com o conceito de "mãe suficientemente boa" e a ênfase na totalidade mãe-bebê que caracteriza a fase inicial do desenvolvimento humano. ${ }^{28} \mathrm{D}$ e fato, Winnicott é 0 autor que dedica maior atenção ao fato de que a relação do bebê com a mãe implica, reciprocamente, uma relação da mãe com o bebê. Para enfatizar esse fato, chegou mesmo uma vez a afirmar que o bebê não existe - 0 que realmente existe é 0 complexo mãe-bebê, no qual um não existe sem 0 outro.

0 reconhecimento da existência de uma pulsão materna hereditariamente constituída não significa, obviamente, que sua manifestação adequada seja automática e independente da experiência individual ou social. Entre os primatas como entre os seres humanos e muitos outros mamíferos, o grau de dedicação materna varia bastante de uma fêmea para outra e as primíparas são freqüentemente mães pouco competentes, do que decorre uma elevada mortalidade entre os primogênitos. Entre os chimpanzés em cativeiro, como vimos, a inexistência de experiência e estímulos promovidos pela vida em grupo não só diminui ou inibe totalmente a fertilidade, como promove o infanticídio direto ou indireto, através do abandono. ${ }^{29}$ No ambiente natural, está amplamente documentado, além do infanticídio promovido por machos de outros grupos quando assumem a chefia de um grupo já constituído, também 0 assassinato da cria de uma fêmea por outra não aparentada (Goodall, 1988).

D eve-se ainda considerar que a ligação entre mãe e cria, ou instinto materno, não se limita a manifestações de amor, mas inclui, e não só 
Revista de Antropologia, São Paulo, USP, 2003, v. 46 № 1.

entre mamíferos, a agressividade contra qualquer outro animal que represente ou possa representar perigo para sobrevivência da prole.

A existência de um instinto parece estar também evidenciada no interesse extremamente precoce das fêmeas por bebês. Jovens chimpanzés fêmeas que mal desmamaram ficam fascinadas pelo nascimento de uma nova cria e procuram, por todos os meios, tirá-las da mãe para carregálas no colo e brincar com elas. Esse comportamento é particularmente visível quando se trata de um irmão ou irmã mais novos, mas não se restringe a eles. Como no caso do sexo, 0 interesse pelos bebês manifesta-se precocemente, embora só se desenvolva plenamente com a gestação e o parto. Aliás, é importante observar que machos jovens e adultos também se interessam por bebês, embora muito menos que as fêmeas e, como vimos, são extremamente tolerantes e até mesmo brincam com eles, numa atitude que chamei de paternidade difusa (Mason, 1965, p. 527).

Há ainda outra observação que deve ser feita em relação a um possível instinto materno, que talvez explique a raridade de relações incestuosas: é a separação que existe, tão claramente nos mamíferos, entre a pulsão sexual e a maternal. Em condições naturais, épocas de acasalamento e de cuidado com os filhotes estão claramente separadas: elas se sucedem mas não se misturam.

A gravidez, o parto, o aleitamento e os cuidados com a prole implicam a interrupção da sexualidade feminina. Embora, entre os chimpanzés, como indicamos, as fêmeas possam retomar o ciclo de receptividade sexual antes do final do aleitamento, não o fazem antes de três anos após o parto, em média; a fertilidade só é restabelecida, como vimos, depois de cerca de quatro a cinco anos após o parto, coincidindo com o desmame. As fêmeas experimentam assim prolongados períodos de suspensão do interesse e da atividade sexual durante pelo menos parte da gestação e durante todo período crucial de três a quatro anos em que estão mais intensamente envolvidas com 0 aleitamento e o cuidado com bebês. 
Numa interpretação freudiana, seríamos levados a admitir que a sexualidade das fêmeas com crias em aleitamento se dirige para os bebês. A hipótese alternativa é a de que a relação de attachment entre a fêmea e a cria se estabelece inicialmente independentemente da sexualidade e mesmo em substituição a ela, como afirma Bowlby.

No caso dos seres humanos, como já observamos, a independência das atividades sexuais em relação às injunções dos períodos de fertilidade, gravidez e aleitamento parece constituir uma adaptação ao desenvolvimento de parcerias sexuais, econômicas e sociais permanentes entre homens e mulheres através do casamento.

\section{Consangüinidade}

Precisamos agora voltar à questão da relação entre mãe e filho para complementar as observações feitas anteriormente.

Não só, como tentamos demonstrar, as relações entre mãe e cria são muito estreitas durante o prolongado período do aleitamento, mas tendem a se prolongar (de modo mais enfraquecido, é claro) por toda a vida.

0 nascimento de uma nova cria, como vimos, não implica o afastamento da cria anterior que continua muito próxima da mãe e, portanto, do novo filhote até a adolescência. Mostramos como, após a adolescência, as fêmeas tendem a abandonar o grupo. Mas os filhos permanecem e continuam a manter relações preferenciais não só com a mãe, mas com os irmãos e irmãs. D e fato, a mãe e seus filhos de diferentes idades formam coalizões que podem ser cruciais na disputa da chefia e nos conflitos internos de qualquer natureza. Os laços fraternos, por outro lado, persistem mesmo após a morte da mãe como alianças privilegiadas entre machos (Goodall, 1988). Podemos falar na existência de protolinhagens maternas dentro do grupo, muitas vezes hostis entre si. Jane 
Goodall documentou casos de infanticídio perpetrados por membros de uma protolinhagem em relação a filhotes de outras fêmeas. Essas observações introduzem a constatação de uma nova dinâmica na vida social dos chimpanzés, demonstrando uma possível importância da consangüinidade na instituição de alianças.

A questão das relações entre mãe e crias sucessivas nos leva a uma reflexão sobre a ausência do complexo de Édipo, que tem Balint como ponto de partida.

A relevância da obra de Balint para esse nosso estudo reside no fato de que sua teoria pode ser facilmente utilizada numa abordagem comparativa entre homens e primatas, explicitando tanto as semelhanças como as diferenças entre uns e outros. Na revisão que efetua da teoria psicanalítica referente às diferentes fases do desenvolvimento sexual, Balint distingue as áreas anteriores ao complexo de Édipo, que denomina "área da falha básica", como "caracterizada pelo número 2, significando que nela estão envolvidas duas e apenas duas pessoas" (Balint, 1968, p. 25). Essa fase ou área é, portanto, marcada pela relação diádica mãe-filho própria tanto de seres humanos quanto de chimpanzés. A fase edípica propriamente é caracterizada pelo número 3 por envolver, além do sujeito, pelo menos dois outros objetos, em geral, mãe e pai, marcando 0 início de relações conflituosas. ${ }^{30}$ Além disso, ela envolve também 0 uso da linguagem e a "capacidade de elaboração simbólica por parte do sujeito", isto é, pressupõe o contexto da cultura e é, portanto, propriamente humana.

Já dissemos que entre os chimpanzés, na ausência do pai, não pode haver complexo de Édipo. Entretanto, há no desenvolvimento das relações afetivas dos chimpanzés um claro momento de passagem de relações diádicas para triádicas - é aquele que ocorre com o nascimento de uma nova cria, que coincide com o desmame, e é uma fase bastante difícil para os chimpanzés, podendo até mesmo ser dramática, como 
aliás acontece com seres humanos. É novamente Jane Goodall quem apresenta as descrições mais sensíveis e detalhadas sobre essa fase do desenvolvimento infantil entre os chimpanzés. Claramente, é a permanência da cria mais velha junto à mãe que promove a formação da relação triádica. Para a maioria dos demais mamíferos, os filhos do parto anterior são desmamados e se dispersam antes do nascimento da cria seguinte. A psicanálise certamente não ignorou, mas talvez não tenha prestado suficiente atenção a esse fenômeno e à importância crucial da relação entre siblings, como decorrente da criação de relações triádicas potencialmente conflitivas. A antropologia, por outro lado, mostra como as relações entre siblings recebem elaborações culturais extremamente complexas. Embora essas elaborações sejam fundamentais nas teorias do parentesco, seu significado emocional não tem sido muito considerado pelos antropólogos. Mas aqui também podemos nos perguntar se não estamos lidando com elaborações simbólicas de um padrão "natural" e não com uma criação inteiramente autônoma da cultura.

\section{Sociabilidade e amor ao próximo}

Para concluir este ensaio, que já está um tanto longo, precisamos ainda voltar a examinar a questão da sociabilidade.

Afirmar que o homem é um animal social é, para todos nós, um truísmo. Para os antropólogos, a obviedade da questão reside no fato de que o homem, tal como o conhecemos, não sobrevive sem a cultura, a qual exige a vida social. D essa forma, as indagações antropológicas raramente se dirigiram no sentido de perguntar quais as origens da sociabilidade, mas se concentraram nas origens e na evolução do comportamento cultural que nos distingue dos demais animais. Mas, se não podemos imaginar o surgimento da cultura sem a existência prévia de 
alguma forma de vida coletiva, parece-me interessante indagar qual os fundamentos da sociabilidade dos grupos proto-humanos, dos quais descendemos e os quais antecedem a evolução cultural.

Não somos, certamente, os únicos mamíferos sociais. Os evolucionistas têm enfatizado o fato de que a emergência da vida social está associada à sua importância como mecanismos de proteção contra predadores. Mas a vida em grupo não emerge esporadicamente na natureza como decorrência de um cálculo de custo-benefício que leve alguns animais de uma espécie a se associarem espontaneamente e outros não. A vida em grupo aparece sempre como característica de uma espécie em seu conjunto e é própria de algumas e não de outras. Trata-se portanto de um padrão geneticamente estabelecido - as espécies sociais são geneticamente programadas para a vida em grupo e devemos então nos perguntar em que medida este tipo de programação continua atuante no $\mathrm{H}$ omo sapiens. D ois mecanismos me parecem essenciais nessa programação: os que evitam a dispersão dos indivíduos e os que promovem vínculos entre os membros do grupo. O bviamente não podemos incluir o raciocínio e a razão entre esses mecanismos - mas as emoções certamente estão envolvidas. A comparação com os chimpanzés parece-me importante para encaminhar essa questão.

0 problema dos fundamentos da base genética do comportamento social dos chimpanzés já foi muito bem colocado por Köhler, em 1925:

Não constitui exagero afirmar que um chimpanzé mantido em isolamento não é um chimpanzé de verdade. Que certas características da espécie apenas surjam quando estão em grupo, deve-se simplesmente ao fato de que 0 comportamento dos companheiros constitui, para cada indivíduo, o único incentivo adequado para suscitar uma grande variedade de formas essenciais de comportamento. (Köhler, 1957, p. 239) 
É dessa forma que potenciais hereditários, aprendizado e vida social se integram uma vez que, entre chimpanzés, os estímulos não provocam necessariamente reações automáticas, mas permitem respostas flexíveis, influenciadas pela experiência individual e social.

De fato, chimpanzés possuem uma vida social particularmente intensa e complexa. Chimpanzés não são como insetos nos quais a vida social é totalmente programada geneticamente. Ao contrário, o comportamento grupal não elimina a imprevisibilidade e a incerteza. Chimpanzés também não são animais pacíficos e altruístas, nem o grupo é uma realidade que implique a negação da individualidade e da variabilidade. Chimpanzés são, simultânea ou alternadamente, amáveis, carinhosos, afetivos, agressivos, egoístas e mesmo calculistas. Nenhum é igual aos demais e a vida social é construída tanto sobre a solidariedade quanto sobre a rivalidade e há uma complexa luta pelo poder. Em tudo isso, parecem muito semelhantes a nós.

O desdobramento da constatação de Köhler nos leva a analisar a grande complexidade nos mecanismos que atuam na organização da vida grupal dos chimpanzés, dando particular atenção aos vínculos afetivos. Já analisamos anteriormente alguns deles: a hierarquia, a sexualidade, a promiscuidade, as relações entre mães e filhos e a consangüinidade. Cabe agora mencionar a sociabilidade em geral.

Robin Durban chama a atenção para um aspecto fundamental da personalidade chimpanzé que parece constituir uma das bases do comportamento social: é o intenso interesse e curiosidade que demonstram em relação uns aos outros, estando permanentemente atentos a quem está fazendo o quê, onde e com quem. Nisso, diz ele, são extremamente semelhantes a nós. Nas pesquisas que realizou com seus alunos sobre 0 que acontece nas reuniões sociais em bares, restaurantes, festas e inclusive em reuniões departamentais na universidade, chegou à conclusão de que mais de dois terços das conversas é dedicada à discussão de senti- 
mentos pessoais e ao "quem está fazendo o quê com quem". Soma-se a isso o fato de que a grande maioria das produções culturais escritas e os programas de rádio e televisão (e certamente os de maior público) está voltada para a vida dos outros, sejam os personagens reais ou fictícios. A sede das pessoas pelos detalhes da vida particular de indivíduos famosos é insaciável. Os chimpanzés, que não podem falar sobre os outros, têm que se contentar com observações de primeira mão.

Esse tipo de observação do comportamento alheio por parte dos chimpanzés está longe de ser objetivo e desinteressado, mas se apóia sobre um permanente fundo emotivo que envolve desde mera curiosidade, passando por cobiça, ciúme, medo, desconfiança, prepotência, submissão, cautela, alegria, prazer e expectativa de ajuda, chegando à solidariedade desinteressada. 0 interesse pelo que os outros estão fazendo baliza um constante ajustamento do comportamento em relação uns aos outros e implica complexos processos mentais que envolvem a previsão da reação dos parceiros ao comportamento do sujeito, isto é, a autoconsciência, a capacidade de identificação com o outro e a memória de relações passadas. Dessa forma, o desenvolvimento da inteligência humana parece estar muito associado à adaptação à vida em grupo.

As estratégias de acasalamento e a formação de coalizões na disputa pelo poder constituem os melhores exemplos dessa complexidade a qual inclui a capacidade de disfarçar as próprias intenções. E essa capacidade não é demonstrada apenas em relação a outros chimpanzés, mas incluem os próprios seres humanos que convivem com eles, como 0 atesta 0 enorme anedotário dos primatólogos.

Uma experiência comum para comprovar a esperteza dos chimpanzés consiste no pesquisador esconder uma fruta de tal modo que apenas um dos membros de um grupo confinado em outro lugar possa observálo. Q uando todos os chimpanzés são soltos no terreiro onde está a fruta, 
aquele que detém a informação disfarça e não demonstra nenhum interesse pelo local onde o cobiçado prêmio está escondido. Mas, assim que os demais se afastam, corre para desenterrá-la e comê-la sem ter que disputá-la com os outros. Claramente ocorreu um complexo processo que envolveu a previsão do comportamento dos demais e uma avaliação das reações possíveis ao comportamento do sujeito e um ajustamento deste comportamento de acordo com as previsões. Isso demonstra também que a base da vida social não se assenta sobre 0 altruísmo. A ajuda a companheiros em dificuldades, por exemplo, não é automática mas parece decorrer, pelo menos em parte, de um cálculo de custo-benefício de tal forma que não se pode contar com ela incondicionalmente. Além disso, chimpanzés raramente compartilham comida ou cooperam para sua obtenção. As exceções quanto à doação de comida envolvem mães para com filhos pequenos e machos para com fêmeas que estejam cortejando. Essa, aliás, constitui uma das diferenças fundamentais entre a sociabilidade dos chimpanzés e a nossa, como aliás já foi apontado por Clifford G eertz (1978). De fato, a cooperação e a distribuição de alimento constituem uma das bases mais sólidas das sociedades humanas.

Há entre os chimpanzés, entretanto, uma exceção quanto a atividades cooperativas na obtenção de alimento, com subseqüente partilha e esta envolve a caça. Isso parece confirmar a importância da caça na evolução dos homens primitivos.

Mas voltemos aos vínculos "amorosos" e aos vínculos entre membros de um mesmo bando.

D e fato, embora a vida social dos chimpanzés não seja um modelo de altruísmo amoroso, a ampla documentação existente não deixa dúvidas quanto à existência de relações afetivas entre membros de um grupo que se exteriorizam, por exemplo, em manifestações de alegria quando um companheiro, afastado durante algum tempo, retorna à companhia dos outros; ao desconforto e preocupação que exibem quando se vêem 
sozinhos; e à busca frenética com a qual se empenham em juntar-se ao grupo. Nas experiências de laboratório, um animal isolado demonstra muito mais ansiedade do que quando há outro chimpanzé presente. A companhia de outros chimpanzés parece constituir um elemento essencial para o sentimento de segurança individual e uma extensão dos vínculos que demonstramos serem tão importantes entre mães e bebês.

A importância da proximidade com outros indivíduos, além da mãe, começa muito cedo. Entre os mamíferos que normalmente têm partos múltiplos, os irmãos da mesma ninhada brincam uns com os outros. 0 brinquedo constitui de fato uma das características mais interessantes dos mamíferos. Chimpanzés que dão à luz um filhote de cada vez não possuem irmãos da mesma idade. Mas mães com filhos pequenos costumam procurar a companhia umas das outras, o que promove a formação de grupos de brincadeira. Pequenos chimpanzés costumam brincar em grupos de 4 a 5 horas por dia. As brincadeiras envolvem muito contato físico e incluem exploração do ambiente, lutas e perseguições acrobáticas através das árvores. Como acontece com crianças humanas, a companhia de parceiros parece estimular aventuras mais ousadas. Além disso, conforme vimos, adolescentes e mesmo adultos também brincam com filhotes especialmente se forem filhos de sua mãe. Adolescentes também brincam uns com os outros e formam grupos de convivência.

A sociabilidade entre os chimpanzés não é entretanto indiscriminada. Chimpanzés, especialmente fêmeas, mantêm relações preferenciais de longa duração com indivíduos específicos, procurando a companhia do parceiro. Creio que não constitui um antropoformismo afirmar que chimpanzés desenvolvem amizades. Esse fenômeno está documentado em praticamente todas as observações de campo e as realizadas em colônias artificialmente criadas em cativeiro.

As relações de amizade se exteriorizam numa convivência mais freqüente e como apoio contra agressões por parte de outros membros do 
grupo ou em caso de perigo externo e desempenham papel fundamental nas coalizões que são tão importantes nas disputas por posições na hierarquia. Mesmo que um chimpanzé não socorra um companheiro que esteja, por exemplo, sendo atacado por um macho dominante (o medo do macho é maior do que a solidariedade), nem por isto a solidariedade deixa de se manifestar através de grande desassossego e gritos de protestos. Assim que o ataque termina, o companheiro se aproxima da vítima para confortá-la.

A teoria do attachment de Bowlby, a qual nos referimos anteriormente, parece ser, como ele mostra, muito adequada para explicar os vínculos interindividuais que os chimpanzés estabelecem entre si. De fato, chimpanzés, como seres humanos, parecem estar geneticamente equipados para desenvolver esse tipo de relações afetivas.

O s vínculos afetivos, como as demais relações, apóiam-se sobre um complexo sistema de comunicação. Em primeiro lugar, há que indicar a importância das vocalizações que constituem um modo fundamental de comunicação. Chimpanzé, como a grande maioria dos primatas sociais, são extremamente barulhentos e os diferentes tipos de gritos e grunhidos são capazes de expressar mensagens diferenciais: perigo e pedidos de socorro, alegria, raiva, queixas, solicitações e solidariedade. Igualmente importantes são as expressões corporais e faciais as quais parecem abranger uma amplitude de significados pelo menos tão grande quanto as vocalizações. É por essa razão que eles são tão bons figurantes em documentários e em filmes de ficção. Melhor do que qualquer descrição que eu possa fazer é a observação de um desses filmes com os quais, tenho certeza, os leitores já tiveram algum contato.

Particularmente importante para a comunicação, a criação e consolidação de relações interindividuais, especialmente as de cunho afetivo, é o contato corporal. Já apontamos a importância do contato com o corpo materno na relação mãe-bebê. Essa importância do contato corporal 
Revista de Antropologia, São Paulo, USP, 2003, v. 46 № 1.

permeia toda a sociabilidade adulta e constitui inclusive um mecanismo fundamental de pacificação, após um conflito, e de restabelecimento de relações amistosas.

A alegria ao encontrar um companheiro se expressa, por exemplo, através de abraços e "beijos". A aproximação com intenções amistosas se manifesta na mão estendida, com a palma para cima, que é tocada ou "beijada" pelo parceiro. Machos derrotados numa disputa manifestam intensa perturbação através de gritos e só se acalmam quando o vencedor os toca com a mão, em palmadinhas carinhosas.

Mas na expressão e consolidação dos laços afetivos, na pacificação de indivíduos raivosos e no consolo de companheiros frustrados ou derrotados, há uma forma de contato corporal extremamente importante, que consiste no tipo de comportamento designado em inglês como grooming, que envolve a minuciosa inspeção da pele e do pêlo para remoção de sujeiras e parasitas. $\mathrm{O}$ grooming se assemelha ao cafuné brasileiro quando este inclui (como era comum no passado) o despiolhamento.

Esse tipo de cafuné é uma atividade absorvente nos primatas em geral e chega a ocupar um quarto do tempo em que estão acordados. É freqüente observar esse cuidado com o pêlo envolvendo mães e seus filhos: ocorre entre adultos, tanto machos como fêmeas; independentemente de sexo. Machos adultos passam grande parte do tempo, quando não estão buscando alimentos, catando-se uns aos outros, o que parece consolidar a solidariedade grupal e a formação de coalizões de machos na disputa pelo poder. Esse comportamento é também freqüente entre machos e fêmeas no cio e constitui, de fato, uma atividade extremamente absorvente para todos os chimpanzés. Os antropólogos não se preocuparam em registrar essa prática em outras sociedades humanas. Mas Malinowski inclui em A vida sex ual dos selvagens uma fotografia, a de $\mathrm{n}^{\mathbf{0}}$. 25, que mostra um homem agachado e uma mulher ajoelhada atrás dele, com as mãos na sua cabeça, com a observação de que 0 
despiolhamento constitui uma das únicas manifestações públicas de carinho permitidas entre marido e mulher.

0 cafuné tem funções higiênicas, pois parece essencial para a manutenção da pelagem. Mas a motivação não é, obviamente, uma preocupação com a higiene. Ele envolve, de fato, ao que se pode depreender, um intenso prazer corporal tranqüilizante.

Robin D unbar, que trabalhou entre os babuínos, parece ter tido experiência de uma sessão de cafuné desse tipo. Diz ele:

Ser objeto de uma sessão de grooming nas mãos de um macaco é experimentar emoções primordiais: 0 frisson inicial de incerteza numa relação não testada, a gradual submissão aos dedos ávidos do outro que percorrem sabiamente a pele nua, o leve beliscar, espremer e mordiscar da epiderme enquanto as mãos se movem de uma sarda para a descoberta surpreendente de uma verruga. A leve dor momentaneamente desconcertante de um beliscão cede lugar imperceptivelmente a uma sensação de prazer tranqüilizante, que se espraia lentamente a partir do centro de atenção. Começase a relaxar na pura intensidade da atividade, submetendo-se deliciosamente ao vaivém das marés de sinais neurais que tecem seu caminho da periferia do corpo até o cérebro, tamborilando sinais para a mente consciente e atingindo algum lugar do centro profundo do ser. (Dunbar, 1998, p. 1)

A importância do contato corporal entre os chimpanzés, que envolve tanto a relação entre mães e filhos como entre adultos, sugere uma comparação com as demonstrações amorosas entre seres humanos. De fato, o contato corporal é mais freqüente entre os chimpanzés do que entre nós. Mas, embora entre os seres humanos o contato corporal seja controlado culturalmente, além do beijo (aliás, mais raro), tocar as mãos e abraçar parecem constituir demonstrações universais de carinho. Parece-me particularmente relevante que, em situações altamente emotivas 
(situações de perigo, morte, funerais e casamentos), as pessoas se abracem e que 0 abraço, nestas circunstâncias, parece-se muito com o holding que caracteriza a relação entre mãe e bebê, tendo aparentemente a mesma conotação de amparo e proteção.

Em conclusão, apesar de ter utilizado uma parcela muito pequena da bibliografia, espero ter mostrado que chimpanzés nascem geneticamente equipados para desenvolver laços afetivos com a mãe e outros indivíduos, um intenso e permanente interesse (e curiosidade) pelo comportamento dos membros do seu grupo, uma dependência da presença dos outros como estímulo para o desenvolvimento de inúmeros comportamentos específicos e para os sentimentos de segurança individual.

\section{Conclusão}

A observação do comportamento emocional dos chimpanzés demonstra a existência de paralelismos inegáveis com a vida psíquica humana, que podem ser extremamente relevantes tanto para a teoria analítica como para a antropologia.

A pesar dos riscos inerentes de antropomorfismo ou de projeções em pesquisas sobre o comportamento de animais, inferências subjetivas não devem ser, por isso, inteiramente deslegitimadas. As técnicas de observação precisam obviamente ser controladas. Mas as semelhanças que sentimos subjetivamente são decorrência do processo evolutivo que nos une aos demais animais em termos de ascendência comum e esta continuidade fundamenta uma possibilidade de comunicação emocional entre seres humanos e outros animais a qual, certamente, faz parte do nosso equipamento psíquico.

A melhor comprovação disso reside não apenas no fato de que podemos prever o comportamento dos chimpanzés, embora isto seja verda- 
deiro, mas na surpreendente descoberta de que eles podem prever 0 nosso, interpretar corretamente nossas intenções e se comunicar conosco. Mas, ainda, as relações afetivas que pesquisadores estabelecem com os chimpanzés têm como contrapartida as relações afetivas que eles desenvolvem em relação aos seres humanos.

Escolhi, para ilustrar as relações afetivas, um relato de Köhler, que foi um dos primeiros a realizar observações sistemáticas e controladas com chimpanzés vivendo em grupo:

Uma noite, quando chovia a cântaros, ouvi dois animais, que eram mantidos isolados num cercado especial, reclamando amargamente. Corri até lá e descobri que o tratador os havia deixado ao relento, tendo quebrado a chave do abrigo onde podiam se esconder da chuva. Forcei a fechadura e consegui abrir a porta, ficando de lado para que os chimpanzés pudessem correr rapidamente para seu abrigo quente e seco. Mas, embora a chuva fria escorresse de todos os lados sobre os corpos trêmulos de frio dos chimpanzés, embora eles tivessem demonstrado a maior infelicidade e impaciência e eu próprio permanecesse no meio da chuva pesada, antes de correrem para 0 abrigo eles se viraram e me abraçaram, um em torno da cintura, outro ao redor do joelho, numa alegria frenética. Apenas depois disso é que mergulharam na palha seca e quente do abrigo. (Köhler, 1957, p. 250)

Se podemos ter alguma dúvida quanto ao fato de sermos semelhantes aos chimpanzés, desconfiando do antropomorfismo, eles próprios parecem ter certeza de serem semelhantes a nós, de poderem ser entendidos por nós, de se comunicarem conosco, de nos compreenderem e, inclusive (pelo menos até certo ponto), de nos amarem. 
Revista de Antropologia, São Paulo, USP, 2003, v. 46 № 1.

\section{Notas}

1 Os americanos, é verdade, mantiveram durante mais tempo uma preocupação com os aspectos universais da cultura e sua base biológica. Pode-se ver isso claramente nos clássicos manuais de antropologia das décadas de 1930, 1940 e 1950, como os de Linton e Herskovits. Mas a antropologia americana recente deixou inteiramente de lado essas preocupações.

2 Na verdade, a obra de Lévi-Strauss contém também alguns pequenos primorosos trabalhos sobre a influência emocional, especialmente "A eficácia simbólica" e "O feiticeiro e sua magia", além de passagens de 0 pensamento selvagem (1962), nas quais se salienta o caráter simultaneamente intelectual e afetivo da "lógica do concreto" (Cap. II, p. 50 ss.)

3 Os documentários que se popularizaram recentemente, especialmente os que dizem respeito aos chimpanzés, apresentam, entretanto, distorções perigosas. Pelo fato de geralmente focalizarem um ou outro aspecto específico da vida dos animais observados, eliminam a complexidade e diversidade da sua vida social. Assim, bonobos são retratados como ginecocraciais e chimpanzés, ora como caçadores sanguinários, ora como idílicos pacifistas.

4 Para uma abordagem recente dessa questão, ver Ekman e Friesen (1998).

5 São particularmente relevantes, para este trabalho, as observações de Köhler relativas à expressão e comunicação das emoções entre os chimpanzés, especialmente 0 anexo intitulado "Algumas contribuições para a psicologia dos chimpanzés" (Köhler, 1957). Ver também Yerkes e Yerkes (1929).

6 Para uma súmula dos estudos de campo sobre antropóides, ver Itami (1998).

7 Wallman (1982) apresenta uma excelente análise crítica do conjunto desses trabalhos.

8 O Velho Testamento, entretanto, descreve muitas outras relações às quais aplicaríamos o termo amor. D eus mesmo manifesta preferências afetivas muito marcadas. Por exemplo, amava mais Abel que Caim, e Jacó em oposição a Esaú. Além do 
mais, o Velho Testamento celebra a paixão de Jacó por Raquel, a de Salomão por Sulamita e condena a paixão de Davi por Betsabá. A preferência do pai por um de seus filhos tem um lugar de destaque, como o caso do amor de Israel por José.

9 Haveria ainda que notar a superposição de significados entre as palavras amar e gostar. Esta última é mais independente de conotações sexuais.

10 Para um conhecimento mais detalhado dos bonobos, além das coletâneas citadas a seguir, é particularmente informativo o livro de Waal: Bonobo, The forgotten apes (1997). A preferência pelos chimpanzés neste trabalho se deve ao fato de que os estudos são muito mais abundantes e os trabalhos de campo, tanto como as experiências de laboratório, mais antigos e abrangentes, incluindo observação continuada de diversas gerações.

11 Utilizamos o conceito de grupo e não de sociedade para designar um conjunto de indivíduos que se reconhecem mutuamente e se contrapõem a outros indivíduos ou agrupamentos da mesma espécie. A identificação recíproca dos membros do grupo é a referência central do conceito.

12 Além dos trabalhos de campo, é particularmente importante o trabalho de Waal com a colônia do zoológico de Arnhem, Chimpanze politics, de 1989, e o já citado trabalho de Dunbar (1998, p. 19).

13 Para informações mais detalhadas sobre esses antropóides consultar especialmente as coletâneas publicadas por McG rew et al. (1996) e D evore (1965). Para os gorilas, em especial, ver Schaller (1963 e 1967), Fossey (1983), Watts (1996) e Tutin (1996). Sobre os chimpanzés, a bibliografia final contém as referências aos trabalhos utlizados que incluem Goodall (1965 e 1998), Hashimoto e Furuichi (1994), Köhler (1957), Mason (1965), McG rew (1992), McG rew et al. (1996), Magnew (1992), Reynolds e Reynolds (1965), Waal (1989 e 1997) e Wragham (1994).

14 No caso dos gorilas, os grupos podem também envolver mais de um macho adulto.

15 A palavra "instinto" está muito desacreditada na biologia e na psicologia. Entretanto, está constantemente presente no senso comum e reemerge freqüentemente 
na literatura. A té um autor tão renomado como Steven Pinker intitula um de seus livros The language instinct. John Bowlby também se vê forçado freqüentemente a recorrer a esse termo. Utilizo-o neste trabalho e 0 aplico a impulsos que fazem parte do equipamento genético humano e que tendem a produzir reações afetivamente carregadas, que são comuns a todos ou quase todos os membros de uma espécie, e que podem se manifestar independente da aprendizagem.

16 Para o conceito de pulsão utilizamos, basicamente, além do próprio Freud, o trabalho de Mezan, Freud: a trama dos conœitos (p. 151 e ss.), e o de Hanns, A teoria pulsional na clínica de Freud.

17 Para uma análise detalhada dessas práticas ver Hrdly (2000).

18 Para os gorilas, entretanto, ao lado do comportamento tolerante para com os bebês do grupo, é freqüente o infanticídio sistemático que ocorre.

19 Ver também Schaller (1963), no qual também se encontra um excelente levantamento sobre a história dos estudos sobre gorilas, anteriores à década de 1960.

20 Experiências com neonatos rhesus, chimpanzés e humanos indicam, entretanto, um declínio dessa capacidade entre estes três primatas. Assim, a capacidade inicial de agarrar-se sem suporte é de cerca de 30 minutos para neonatos rhesus, cinco para chimpanzés e dois para seres humanos.

21 Para uma análise da extensa bibliografia a respeito, ver Bowlby (1961) e Hrdly (2000).

22 Bowlby (1958) faz crítica semelhante.

23 No artigo citado em nota anterior, Bowlby faz a mesma crítica.

24 D as muitas outras experiências, a maior parte das quais está ligada a tentativas de ensinar antropóides a falar. Para um resumo crítico dessa e de outras experiências, ver Wallman (1982) e D unbar (1998). 
250 conceito de attachment foi traduzido em português por "relação de ligação", que é bastante insatisfatório, pois nele se perde a polissemia do conceito original.

26 Devo, ao psicanalista Paulo Duarte, a indicação da obra de Bowlby, com o qual tomei contato após ter redigido a primeira versão deste trabalho. Encontrei uma congruência tão grande entre a orientação e as conclusões desse autor e as minhas, que cheguei a pensar em abandonar meu artigo, pois ele tinha deixado de ser original, como me parecera antes. Como, entretanto, Bowlby é ainda desconhecido para os antropólogos e não parece ser muito utilizado pelos psicanalistas, acabei concluindo que este meu trabalho ainda tinha sentido embora, nos limites deste artigo, a teoria daquele autor não possa ser examinada em todas suas ramificações.

27 Ver nota 15 sobre 0 uso do termo instinto.

280 conceito de "mãe suficientemente boa" tem uma dupla conotação: é essencial ao bebê que a mãe seja suficientemente boa, mas não é necessário, e é mesmo indesejável, que seja boa demais.

29 Aliás, o infanticídio é uma ocorrência freqüente entre animais e não só mamíferos. Para uma análise detalhada da questão do infanticídio e do abandono, assim como sobre o aleitamento na espécie humana, consultar Hrdly (2000, especialmente os capítulos 8, 12 e 14). No caso dos chimpanzés, G oodall (1988) documenta 0 assassinato de bebês de uma fêmea por outra fêmea.

30 Ver mais adiante a questão do desmame. 


\section{Referências bibliográficas}

BALINT, M.

1968

The Basic Fault. London, Tavistock.

BOWLBY, J.

1958

"The nature of child's tie to his mother". International Journal of Psychoanalysis, 39(5).

2001 Formação e rompimento dos laços afetivos. São Paulo, Martins Fontes.

DAMÁSIO, A. R.

1984 D escartes' error. E motion, reason and the human brain. New York, Putnam.

1998 et al. "Somatic Markers and the guidance of behavior". In: JENKINS, J. M. et al. (Eds.) H uman E motion. A reader. Malden/ Oxford, Blackwell.

20000 mistério da consciência. D 0 corpo e das emoções ao conhecimento de si. São Paulo: Companhia das Letras.

DARWIN, Charles.

1965 The expression of the emotions in man and the animals. Chicago, University of Chicago.

DAWKINS, R.

1976

The selfish gene. New York, Oxford University.

DEVORE, I.

1965

(Ed.) Primate Behavior. Field studies of monkeys and apes. New York/ Chicago/ London, Rineheart and Winston.

DUNBAR, R.

1998

Grooming, gossip and the evolution of language. Cambridge, Massachusetts, Harvard University.

EKMAN, P. \& FRIESEN, W. E.

1998

"Constants across culture in the face of emotion". In: JENKINS, J. M.; OATLEY, K. \& STEIN, N. L. (eds.). H uman emotions. A reader. Malden/ Oxford, Blackwell, p. 270-87. 
FOSSEY, D.

1983 G orillas in the mist. Boston, Houghton Mifflin Cy.

FREUD, S.

1905 "Three essays on sexuality". Standard E dition, vol. XVII.

1914 "On narcissism: An introduction". Standard E dition, vol. XIV.

1940 "An outline of Psycho-Analysis". Standard E dition, vol. XXIII.

FRIDJA, N. H.

1998 "The laws of emotion". In: JENKINS, J. M.; OATLEY, K. \& STEIN, N. L.

(Eds.) H uman emotions. A reader. Malden/ Oxford, Blackwell, p. 270-87.

GEERTZ, C.

1978 A interpretação das culturas. Rio de Janeiro, Zahar, parte II.

GOLEMAN, D.

1995 Inteligência emocional. Rio de Janeiro, Objetiva.

GOODALL, J.

1965

"Chimpanzees of the Gombe Stream Reserve". In: DEVORE, I. Primate behavior. Field studies of monkeys and apes. New York/ Chicago/ San Francisco/ Toronto/ London/ Holt, Rinehant and Winston.

1988 In the shadow of man. Boston, Houghton Mifflin Cy.

HANNS, L.

1999 A teoria pulsional na clínica de Freud. Rio de Janeiro, Imago.

HASHIMOTO, C. \& FURUICHI, T.

1994 "Social role and development of noncopulatory sexual behavior of wild bonobos". In: WRANG HAM, R. W; McGREW, W. C.; WAAL, F. B. M. de. \& HELTRE, P. G. Chimpanze cultures. Cambridge/ London, Harvard University.

HERSKOVITS, N. J.

1947 Man and his works. The scienœe of cultural A nthropology. New York, Alfred A. Knopf. 
HINDE, R. A.

1971

"Effects of brief separation from mother in rhesus monkeys". Scienœ, 173.

HRDLY, S. B.

2000

Mother $\mathrm{N}$ ature. Maternal instincts and how they shape the human species. New York, Ballantine Books.

ITAMI, J.

1998

"Afterword: a new milestone in great ape research". In: JENKINS, J. M. et al. H uman emotions. A reader. Malden/ Oxford, Blackwell.

JAMES, William.

1950 The Principles of psychology. New York, Dover.

1952 The Principles of psychology. Chicago, Encyclopaedia Britannica.

JENKINS, J. M.; OATLEY, K. \& STEIN, N. L.

1998 (Eds.) H uman emotions. A reader. Malden/ Oxford, Blackwell.

JUNG, C. J.

1996 The collective works. $2^{\text {nd }}$ ed. London, Routledge, vol. XVI.

KÖHLER, W.

1957 The mentality of apes. Harmondsworth, Middlesex, Penguin Books (1르 publicação em alemão em 1925).

LÉVI-STRAUSS, C.

1958b "Le sorcier et sa magie". In: A nthropologie Structurale. Paris, Plon.

1962 L a pensée sauvage. Paris, Plon.

LEVY-BRUHL

1947 La mentalité primitive. Paris, Presses Universitaires de France.

LINTON, R.

1936 The study of man. A $\mathrm{n}$ introduction. New York, Apleton-Century. 
LOY, J. D. \& PETERS, C. B.

1991

U nderstanding behavior. W hat primate studies tell us about human behavior. New York, O rford University.

\section{MALINOWSKI, B.}

1972

A vida sex ual dos selvagens. Rio de Janeiro, Francisco Alves.

MASON, W. A.

1965

"The social development of monkeys and apes". In: DEVORE, I. Primate behavior. Field studies of monkeys and apes. New York/ Chicago/ San Francisco/ Toronto/ London/ Holt, Rinehant and Winston.

MCGREW, W. C.

1992 Chimpanzee material culture. Implications for human evolution. Cambridge, Cambridge University.

1996 ; MARCHANT, L. F. \& NISHIDA, T. (Ed.) G reat A pes societies. Cambridge, Cambridge University.

MEZAN, R.

1998 Freud: a trama dos conceitos. São Paulo, Perspectiva.

OGDEN, T. H.

1989

The primitive edge of ex perience. London/ New York, Northwale/ Jason Arsonson.

OLIVEIRA, R. C.

1991 "Razão e afetividade. O pensamento de Levy-Bruhl". CLE 0. Campinas, Unicamp, vol. 8.

REYNOLDS, V. \& REYNOLDS, F.

1965

"Chimpanzees of Budongo Forest". In: DEVORE, I. Primate behavior. Field studies of monkeys and apes. New York/ Chicago/ San Francisco/ Toronto/ London/ Holt, Rinehant and Winston.

SCHALLER, G. B.

1963 The mountain gorilla. Ecology and behavior. Chicago/ London, Chicago University. 
s./ d. L L vida del gorilla. México, Fondo de Cultura Econômica (1ª edição em inglês, 1964).

WAAL, F. de.

Chimpanzee politics. Power and sex among apes. Baltimore/ London, The John Hopkins University.

1997 \& LANTING, F. Bonobo. The forgotten apes. Berkeley/ Los Angeles/ London, University of California.

WALLMAN, J.

1982 A ping language. Cambridge, Cambridge University Press.

WINNICOTT, D. W.

1975 Through pediatrics to psycho-analysis. New York, Basic Books, Collected papers. $1990 \quad$ Natureza humana. Rio de Janeiro, Imago.

1991 The child, the family and the outside world. Harmonds Worth, Penguin Books (First published 1964).

WRAGHAM, R. W. et al.

1994 Chimpanzee cultures. Cambridge, Harvard University.

YERKES, R. M. \& YERKES, A. W.

1929

The G reat A pes. New Haven, Yale University. 


\begin{abstract}
The general objective of this article is to call the attention of anthropologists to new developments of biological sciences like Neurobiology, Primatology, Ethology and studies and theories regarding evolution which should promote a revision of assumptions present in Anthropology regarding the classical opposition nature-culture. This general problem is analyzed through a comparison between chimpanzees and humans, focusing on the emotional components of behavior. More specifically, it analyses "love" behavior and includes sexual behavior, mother-child, sibling and friendship relations. It also analyses the importance of emotional components for the constitutions and continuity of social groups. A brief mention is made regarding hierarchy, aggression and political alliances. The comparison raises questions regarding incest, homosexuality and marriage which involves also a dialogue with Psychoanalysis.
\end{abstract}

KEY-WORD S: chimpanzees; human culture and animal behavior; man and other primate.

Recebido em dezembro de 2002. 